\title{
Testing Wetland Delineation Indicators in New England Boulder Fields
}

Robert W. Lichvar, Katherine E. Curtis,

Jennifer J. Gillrich, and Lindsey E. Dixon

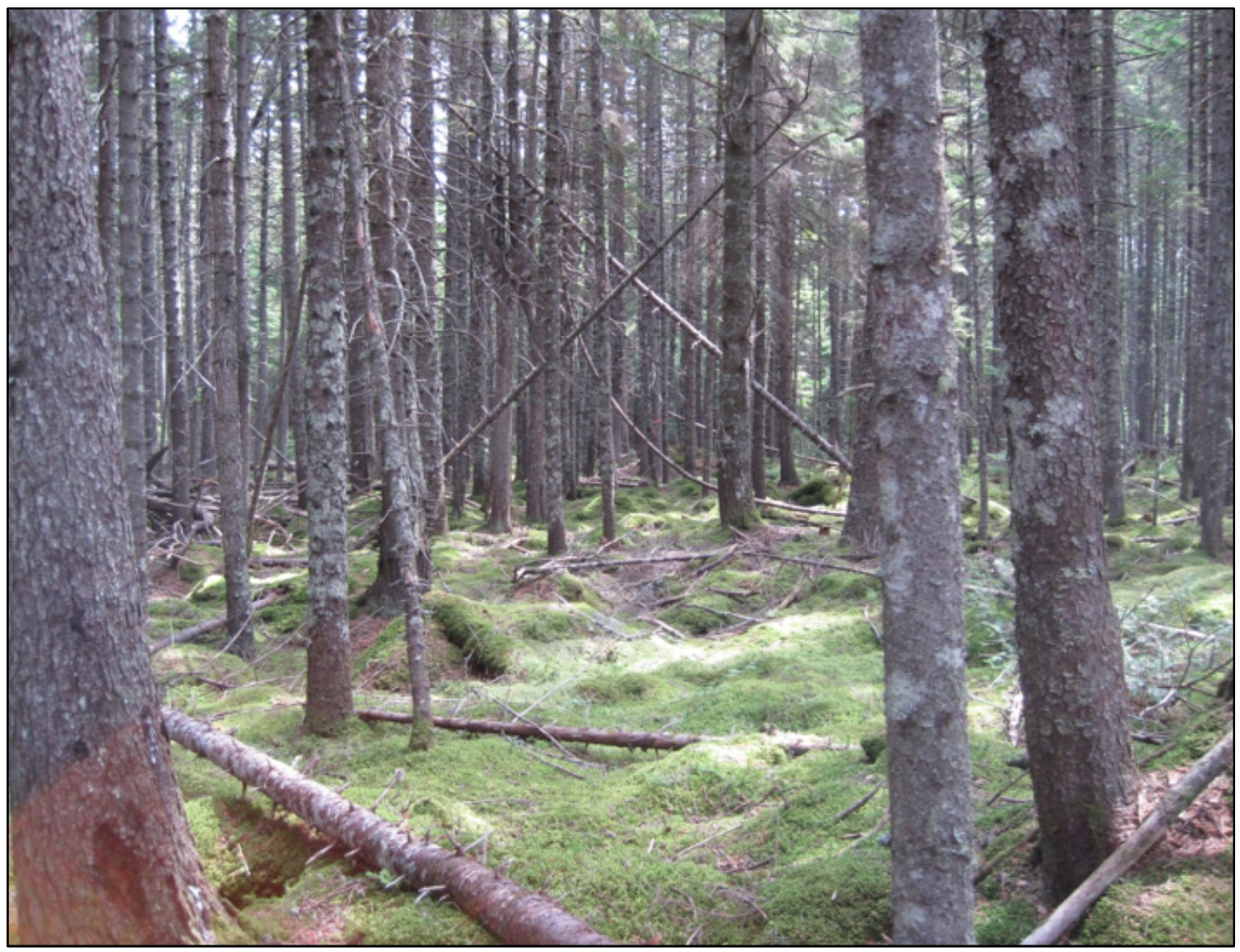




\section{Testing Wetland Delineation Indicators in New England Boulder Fields}

Robert W. Lichvar, Katherine E. Curtis, Jennifer J. Gillrich, and Lindsey E. Dixon

Cold Regions Research and Engineering Laboratory

U.S. Army Engineer Research and Development Center

72 Lyme Road

Hanover, NH 03755

Approved for public release; distribution is unlimited.

Prepared for New England District, Regulatory Division

U.S. Army Corps of Engineers 


\section{Abstract}

We evaluated the potential for regulating wet boulder fields as wetlands or other "Waters of the US" under Section 404 of the Clean Water Act. We monitored hydrology in two boulder fields in Maine during the 2011 growing season and documented the presence/absence of hydric soil, wetland hydrology, hydrophytic vegetation, and Ordinary High Water Mark (OHWM) indicators. The wetland hydrology criterion was statistically associated with the presence of primary hydrology indicator $\mathrm{C}_{4}$, hydric soils, FACU-dominated wetland, and a separation between the folist layer and the soil surface. The occurrence of hydrophytic vegetation and the combined use of primary and secondary hydrology indicators were not associated with the wetland hydrology criterion. Wet boulder fields should be delineated as wetland/nonwetland mosaics that contain problematic wetland types. We strongly suggest discontinuing the use of secondary hydrology indicators and primary indicator B8 (sparsely vegetated concave surface) in wet boulder fields. Alpha,alpha-dipyridyl paper strips are the most accurate method for determining if a primary hydrology indicator is present. We recommend applying this test several times over 14 days. IRIS tubes and hydric soil indicators are reliable, but we suggest that alpha, alpha-dipyridyl paper strips be used to confirm a determination of nonhydric soil when a soil lacks a hydric soil indicator.

DISCLAIMER: The contents of this report are not to be used for advertising, publication, or promotional purposes. Citation of trade names does not constitute an official endorsement or approval of the use of such commercial products. All product names and trademarks cited are the property of their respective owners. The findings of this report are not to be construed as an official Department of the Army position unless so designated by other authorized documents. 


\section{Table of Contents}

Abstract........................................................................................................................................ if

List of Figures and Tables .................................................................................................

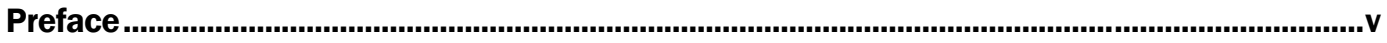

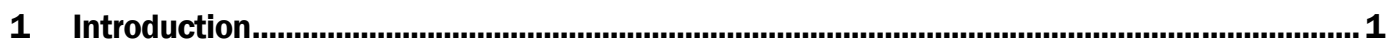

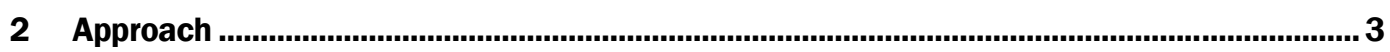

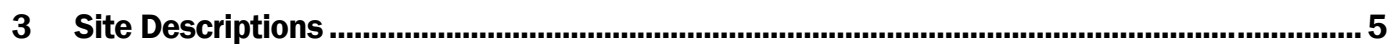

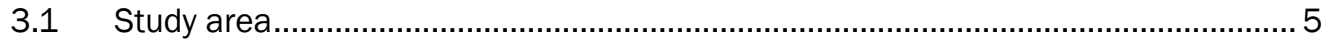

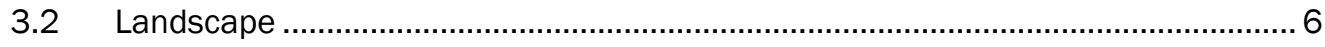

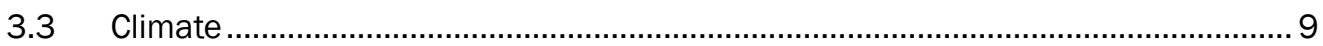

4 Methods...................................................................................................................................12

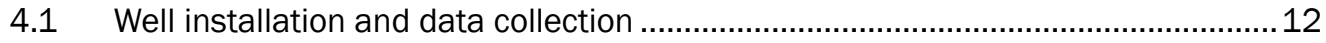

4.2 Documenting wetland indicators..................................................................... 15

4.3 Calculating the PI, the DR, and the FN-DR .................................................. 17

4.4 Statistical analysis........................................................................................... 19

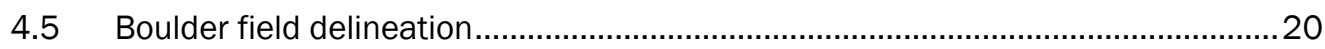

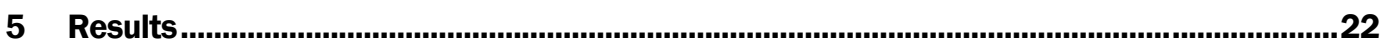

$5.1 \quad$ Water table levels ...................................................................................... 22

5.2 Statistical analysis.............................................................................................. 24

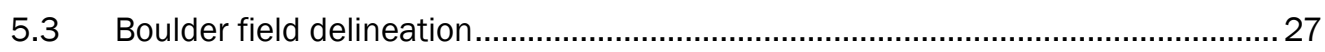

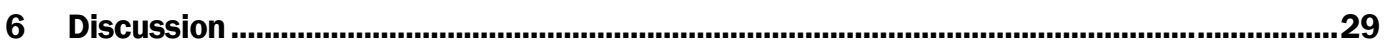

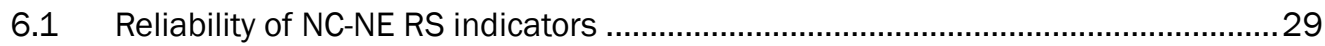

6.2 Delineating the OHWM in wet boulder fields ........................................................ 31

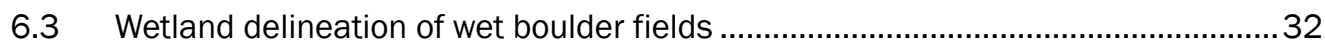

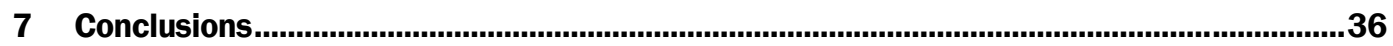

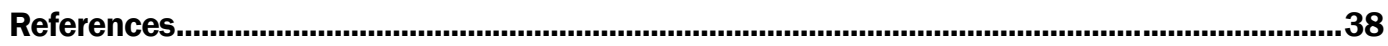

\section{Report Documentation Page}




\section{List of Figures and Tables}

\section{Figures}

Figure 1. Locations of boulder fields in Rangeley and Greenville, ME 5

Figure 2. Topographic map of the Saddleback Mountain boulder field, Rangeley, ME ..................... 6

Figure 3. Site photographs of the Saddleback Mountain boulder field near Rangeley, ME .............. 7

Figure 4. Topographic map of the Burnt Jacket boulder field, Greenville, ME ................................. 8

Figure 5. Site photographs of the Burnt Jacket boulder field near Greenville, ME ............................ 8

Figure 6. Daily precipitation from May-September 2011 at the Rangeley and Moosehead weather stations

Figure 7. Sites with and without a separation between the folist layer and the soil surface .......... 13

Figure 8. Shift adjustment using the manual measurement from each month ..............................23

Figure 9. OHWM indicators at Saddleback in Rangeley, ME ...................................................... 32

Figure 10. Methodology recommended for a boulder field delineation .........................................34

\section{Tables}

Table 1. Summary of WETS table showing the average monthly precipitation, the $30 \%$ chance less than and more than thresholds, and the monthly precipitation for MaySeptember 2011

Table 2. Profile for each well describing the thickness of the folist layer, the thickness of the separated surface between the folist layer and mineral soil, the soil profile, and additional comments about the well characteristics

Table 3. Summary of the water table monitoring throughout the growing period as adjusted using the Barologgers and August manual measurement

Table 4. Results from Mann-Whitney tests comparing medians and Fisher's exact tests comparing proportions of soil indicators in all plots

Table 5. Results of Fisher's exact tests comparing the proportion of plots that met the wetland hydrology criterion with the proportion of plots that contained indicators of wetland hydrology, hydric soils, and hydrophytic vegetation described in the NorthcentralNortheast Regional Supplement

Table 6. Summary results showing method used to classify plots into one of four categories for delineation purposes: uplands, three-factor wetlands, FACU-dominated wetlands, and FACU-dominated wetlands with problematic soils 


\section{Preface}

This research was funded by the U.S. Army Engineer District, New England, Regulatory Division. Jennifer McCarthy, Ruth Ladd, and Dr. Paul Minkin are acknowledged for both support and advice.

This report was prepared by Robert W. Lichvar. Katherine E. Curtis, Jennifer J. Gillrich, and Lindsey E. Dixon, all of the Remote Sensing/ Geographic Information Systems (RS/GIS) and Water Resources Branch, Cold Regions Research and Engineering Laboratory (CRREL), U.S. Army Engineer Research and Development Center (ERDC), Hanover, NH. This study was conducted under the general supervision of Timothy Pangburn, Chief, RS/GIS and Water Resources Branch; Dr. Justin B. Berman, Chief, Research and Engineering Division; Dr. Lance Hansen, Deputy Director; and Dr. Robert E. Davis, Director. Permission to publish was granted by Director, Cold Regions Research and Engineering Laboratory.

COL Kevin J. Wilson was the Commander and Executive Director of ERDC, and Dr. Jeffery P. Holland was the Director. 


\section{Introduction}

"Boulder field" is a broadly defined geomorphic term associated with glacial or periglacial processes (White 1981; Washburn 1973). Typically, most of the boulder deposits are remnants of the Pleistocene glacial periods of 50,000-10,000 years before present (BP) (Flint 1963). Generally, boulder fields were deposited as glacial drift or as part of a rock glacier movement or formed during periglacial climates (Potter and Moss 1968). Rock glaciers are geomorphic features where ice forms between the boulders, and the ice and boulders move downslope or in a valley (Wahrhaftig and Cox 1959; Haeberli et al. 1979).

The term "boulder field" can refer to block fields, glacial till, and talus slopes (White 1981). Block fields, or periglacial boulder fields, typically result from repeated freeze/thaw cycles that cause extreme frost cracking of a ledge or bedrock formation (Potter and Moss 1968). Glacial till consists of unsorted rock and sediment deposits that are eroded from the land surface as the glacier moves and are later deposited when the glacier's energy reduces and can no longer transport the sediments. Talus slopes typically represent periglacial and weathered features but are not necessarily glacial deposits. Talus slopes are often erosional features on steep mountain slopes. Glacial and periglacial boulder fields can occur near each other because the extreme temperatures associated with glacial conditions can also affect the adjacent landscape (Cunningham and Wilson 2004).

As many boulder fields are located in topographically low landscapes where glacial activities have eroded drainage patterns, boulder fields may contain flowing water. However, the water may not be at or near the surface of the soil matrix between the boulders. For example, talus slopes are often too steep to store water, and periglacial boulder fields generally lack flowing water because they are a function of repeated freeze/thaw weathering rather than glacial movement (Potter and Moss 1968). Of the various types of boulder fields, those in glacial till and rock glaciers (Clark et al. 1998) have the greatest potential to have stored water in the form of ice. The water movement and location within a boulder field are complex and highly variable. Boulder fields can be a mosaic of wet and dry areas, making these areas potentially problematic wetland types. Determining the hydrologic conditions in a boulder field is challenging because the size and 
arrangement of the boulders make field observations and instrumentation placement difficult.

Wetlands are usually considered to be areas with features such as water at or near the surface, plant species that are specially adapted for living in wet areas, and soils that have been modified to reflect the influence of saturated conditions (Environmental Laboratory 1987). Boulder fields, on the other hand, are typically viewed as geomorphic features that developed from glacial processes and are not usually characterized as wetlands. However, it may be that wetland conditions exist in certain types of boulder fields but they may not be generally recognized because the wetland factors are not obvious. The presence of wetland hydrology can be difficult to observe, and the water depth from the surface can be hard to measure among all the boulders and moss-covered surfaces. Observations of the presence of hydric soil features appear to be inconsistent with the hydrologic patterns (Rocque 2010), and nonhydrophytic plant species grow on top of the boulders and are rooted in the moss duff layer. Therefore, the vegetation may not reflect the hydrologic conditions because the plants are not rooted in the soil matrix located between the boulders.

Boulder fields can also have a folist layer composed primarily of organic material in various stages of decay (Whitty and Arnold 1970) that is separated from the ground surface by $1 \mathrm{ft}$ or more. This separation has led to discussions in the U.S. Army Corps of Engineers (USACE) Wetland Regulatory Program about the definition of a hydric soil and where to start surface measurements needed to identify if a soil is hydric. These unique field conditions-water occurring between the boulders and surfaces that are separated-have resulted in significant debate about whether or not boulder fields meet the definition of a wetland or if they should be delineated by other "Waters of the United States" (WoUS) methods. To be considered WoUS, boulder fields would need an Ordinary High Water Mark (OHWM) to define the lateral extent of non-wetland waters. If there are defined surface features demonstrating an active channel, boulder fields may be regulated by the OHWM. 


\section{Approach}

We monitored the hydrology of two boulder fields in Maine during the 2011 growing season to determine if they met the USACE wetland criteria found in the Corps of Engineers Wetland Delineation Manual (COE Manual) (Environmental Laboratory 1987). We had two goals: to determine the characteristics of wet boulder fields and to describe a delineation methodology.

As the wetland criteria require that a wetland area be periodically inundated or have saturated soils during the growing season (Environmental Laboratory 1987), our first objective was to measure the water table levels in the two boulder fields. These measurements were used to determine if any of the locations met the wetland hydrology criterion that the water table be within the top $12 \mathrm{in}$. of the soil surface for 14 or more consecutive days during the growing season (USACE 2005).

The second objective was to record the presence or absence of the hydrophytic vegetation, hydric soil, and wetland hydrology indicators described in the Northcentral-Northeast Regional Supplement (NC-NE RS) (USACE 2009) to the COE Manual and to determine if the presence of the wetland hydrology criterion is associated with the occurrence of those wetland indicators specified in the regional supplement. We also recorded the presence or absence of a separation between the folist layer and the soil surface, and the percentage of moss cover in each plot, to determine if these variables might be associated with the presence of the wetland hydrology indicators in wet boulder fields.

Our third objective was to determine if boulder fields could be regulated as other Waters of the United States (WoUS) by observing the presence of Ordinary High Water Mark (OHWM) indicators.

Our final objective was to develop a method for delineating the boundaries of wet boulder fields based on statistical associations between the presence of the technical standard for wetland hydrology (hereafter referred to as the wetland hydrology criterion) and the presence of NC-NE RS indicators for hydrology, soils, and vegetation. 
To meet these objectives, we made two types of hypotheses: hypotheses involving quantitative variables, such as the height of the water table, and hypotheses involving categorical variables, such as the presence or absence of wetland hydrology indicators. For tests involving quantitative variables, we used the hydrology technical standard (USACE 2005) to sort plots into two groups and then tested these groups to determine if they were statistically different. We compared plots that met the wetland hydrology criterion vs. those that failed to meet the criterion. We hypothesized that there is no significant difference in the number of days during the growing season that the water table was within the top 12 in. of the soil surface, and no significant difference in the median water levels. We further hypothesized that there is no significant difference in the total percentage of moss cover in plots that met or failed to meet the wetland hydrology criterion.

For categorical tests involving associations between meeting the wetland hydrology criterion and the presence of wetland indicators described in the NC-NE RS (USACE 2009), we hypothesized that there is no significant difference in the proportion of plots that met the wetland hydrology criterion and the proportion of plots that contained either at least one primary or at least two secondary wetland hydrology indicators described in the NC-NE RS, or met primary hydrology indicator $\mathrm{C}_{4}$, soils with ferrous iron as determined using either alpha,alpha-dipyridyl (AAD) paper strips or AAD liquid. With regard to soils, we hypothesized that there is no significant difference in the proportion of plots that met the wetland hydrology criterion and the proportion of plots that contained soils exhibiting at least one hydric soil indicator described in the NC-NE RS, anaerobic soils based on IRIS tube reduction, or soils exhibiting a separation between the folist layer and the soil surface. We further hypothesized that there is no significant difference in the proportion of plots that contained hydric soil indicators described in the NC-NE RS and the proportion of plots that contained a separation between the folist layer and the soil surface. With regard to vegetation, we hypothesized that there is no significant difference in the proportion of plots that met the wetland hydrology criterion and the proportion of plots that contained hydrophytic vegetation determined using either the Dominance Ratio or the Prevalence Index. We also hypothesized that there is no significant difference in the proportion of plots that met the wetland hydrology criterion and the proportion of plots that met the NC-NE RS criteria for FACU-dominated wetlands. Using the results of these hypotheses to characterize wet boulder fields, we determined a delineation methodology appropriate for wet boulder fields. 


\section{Site Descriptions}

\subsection{Study area}

The boulder fields are located in Rangeley and Greenville, ME. The Rangeley boulder field is located near the base of the northwest slope of Saddleback Mountain, and the Greenville boulder field is located east of Burnt Jacket Mountain on the southern end of Moosehead Lake (Fig. 1). The sites are approximately 60 miles apart and are both within the Bailey's (1995) Warm Continental Division Eco-region. This region is characterized by glaciated mountains and dissected plateaus of mountainous topography underlain by granite and metamorphic rocks and thinly mantled by glacial till. Both sites are located within topographic lows and are characterized by rocky hummocks with duff overlying the boulders and hollows that have various depths of surface water present. Both sites are dominated by conifer forests, and boulders located in these sites are approximately 1-4 ft in width. We visited the sites in May, July, August, and October 2011 to collect vegetation and soil data and record water depth measurements at groundwater monitoring wells.

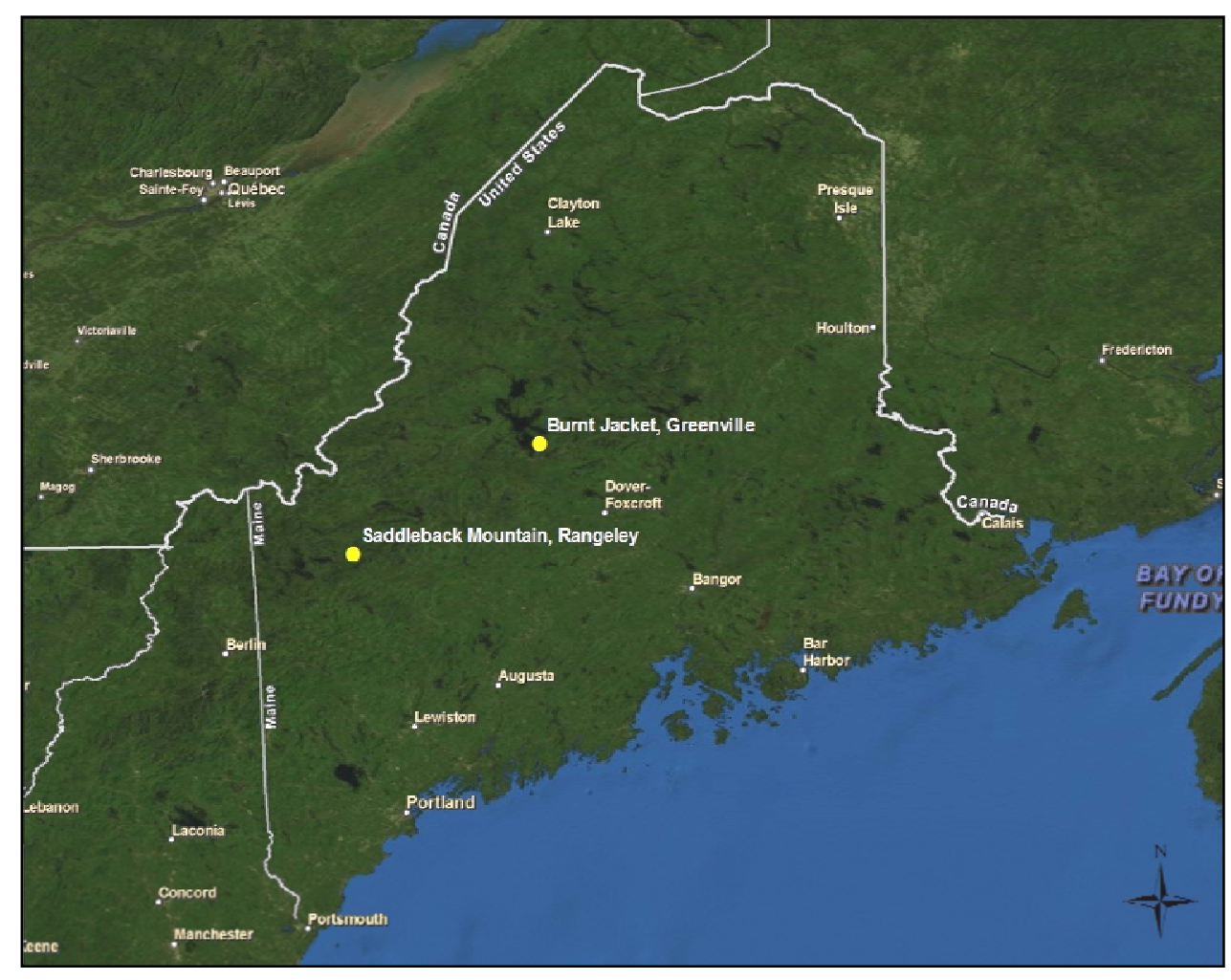

Figure 1. Locations of boulder fields in Rangeley and Greenville, ME. 


\subsection{Landscape}

The Saddleback Mountain boulder field consists of Middle Paleozoic sedimentary rocks (USGS 2006). The soil in this area is mapped as the Colonel-Dixfield association and is described as strongly sloping at $3-15 \%$ and very stony (NRCS 2009). This soil unit is typically located at a footslope in a concave landscape position, with a parent material of coarse loamy lodgement till derived from granite and gneiss, and the depth to the restrictive layer is relatively shallow at 12-24 in. (NRCS 2009). The Saddleback boulder field is located at an elevation of $1830 \mathrm{ft}$ (Fig. 2) and was deposited on the toe of a glacial slope (Fig. 3). Stream channels on multiple sides of the surrounding mountains drain into the basin where the boulder field site is located and flow into Saddleback Lake. In some locations within this concave topography at the boulder field site, water flows around boulders beneath the folist layer.

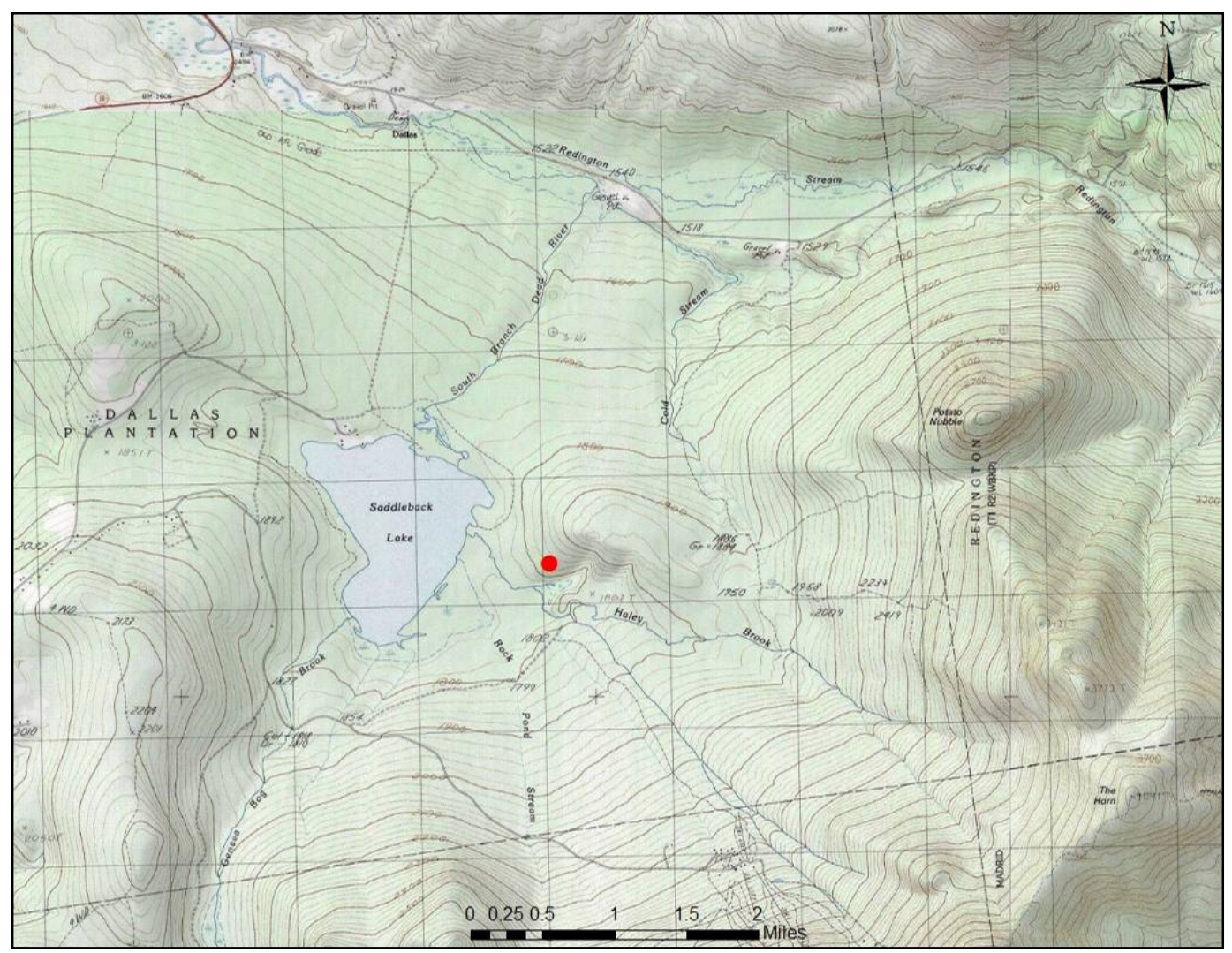

Figure 2. Topographic map of the Saddleback Mountain boulder field, Rangeley, ME. 

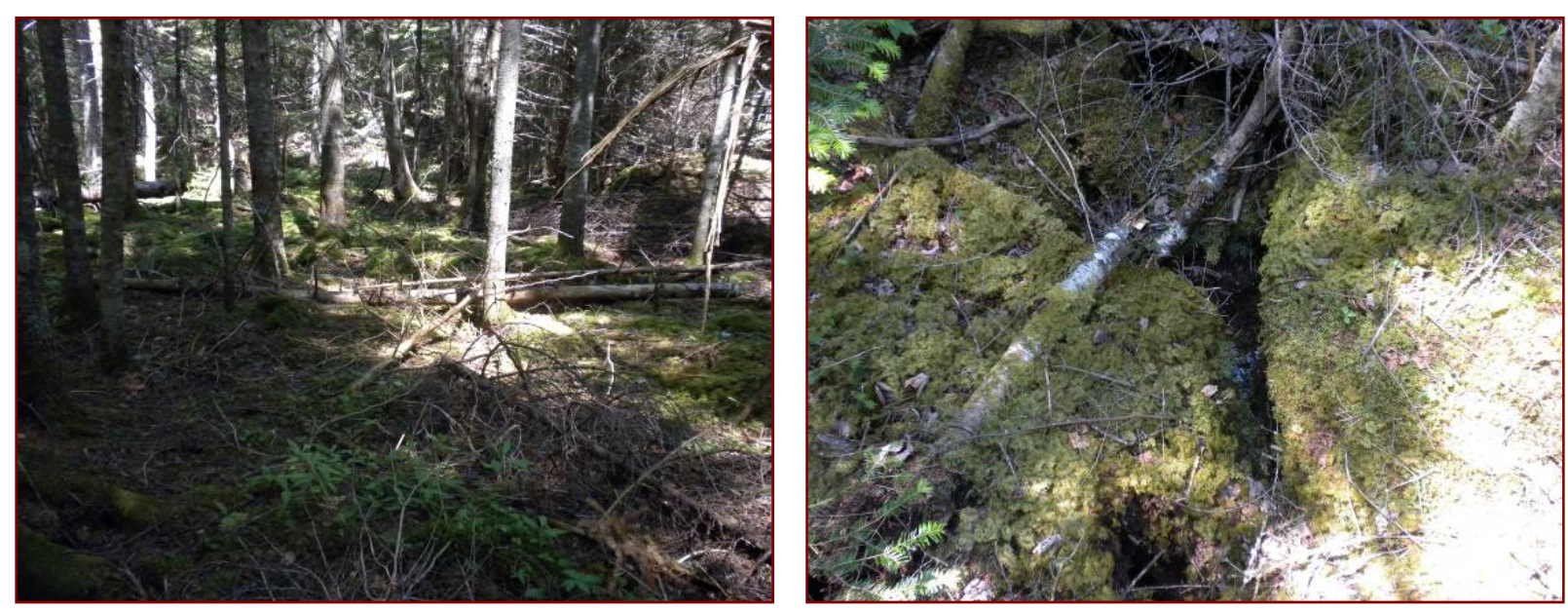

Figure 3. Site photographs of the Saddleback Mountain boulder field near Rangeley, ME.

The Burnt Jacket boulder field is located east of Burnt Jacket Mountain and north of Scammon Ridge (Fig. 4) at an elevation of $1045 \mathrm{ft}$. The geologic formation at this site consists of Middle Paleozoic mafic rocks (USGS 2006). The soil is mapped as the Colonel-Brayton-Dixfield association and is described as gently sloping at $1-8 \%$ and very stony (NRCS 2009). This soil unit is typically found on a backslope with a parent material of coarse, loamy lodgement till derived from granite and gneiss, and the depth to the restrictive layer is fairly shallow at 17-24 in. (NRCS 2009). The topography at the Burnt Jacket boulder field is a gentle slope (Fig. 5), and along the lake shoreline, groundwater seeps around the boulders into Moosehead Lake.

Unlike the Saddleback boulder field, the Burnt Jacket boulder field lacks a clearly defined drainage pattern because the topography at Burnt Jacket is more gently sloped. The upper extent of the study area has recently been clear-cut for a future development, changing the vegetation from a conifer forest to a shrub forb community. 


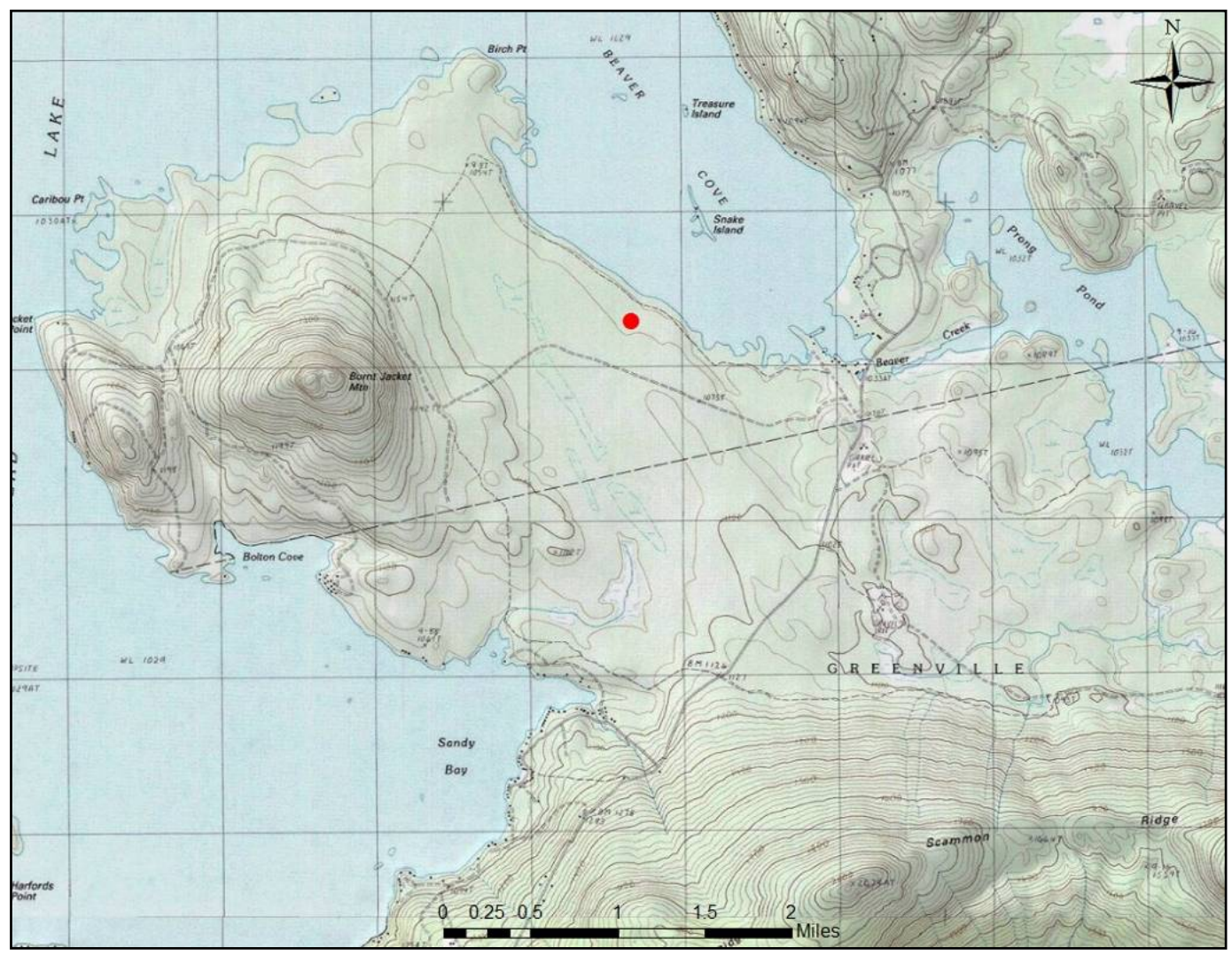

Figure 4. Topographic map of the Burnt Jacket boulder field, Greenville, ME.
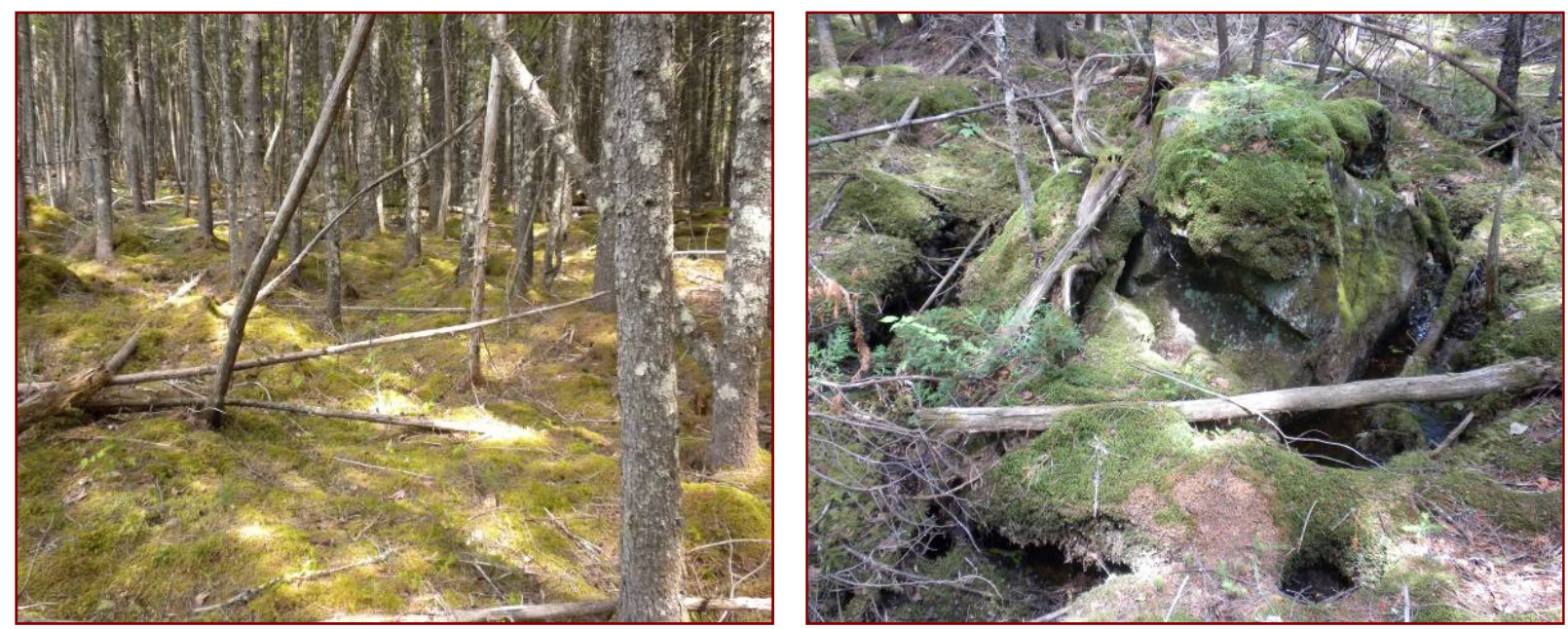

Figure 5. Site photographs of the Burnt Jacket boulder field near Greenville, ME. 


\subsection{Climate}

The climate at both Saddleback Mountain and Burnt Jacket is characterized by mild, warm summers and cold, snowy winters, with frosts common from early fall through late spring. Precipitation is evenly distributed throughout the year (Bailey 1995). Precipitation at Saddleback Mountain averages $40.6 \mathrm{in} .(103.1 \mathrm{~cm})$ per year, and the average snowfall is $115.4 \mathrm{in}$. $(293.12 \mathrm{~cm})$ per year. The average annual temperature is $38.3^{\circ} \mathrm{F}\left(3.5^{\circ} \mathrm{C}\right)$. The average daily high is $49.9^{\circ} \mathrm{F}\left(9.9^{\circ} \mathrm{C}\right)$, and the average daily low is $26.7^{\circ} \mathrm{F}\left(-2.9^{\circ} \mathrm{C}\right)$. At Burnt Jacket, precipitation averages 43.3 in. (109.98 $\mathrm{cm})$ per year, and the average snowfall is $99.2 \mathrm{in}$. $(251.97 \mathrm{~cm})$ per year. The average annual temperature is $43.3^{\circ} \mathrm{F}\left(6.3^{\circ} \mathrm{C}\right)$. The average daily high is $51.8^{\circ} \mathrm{F}\left(11.0^{\circ} \mathrm{C}\right)$, and the average daily low is $29.9^{\circ} \mathrm{F}\left(-1.2^{\circ} \mathrm{C}\right)$. At Saddleback and Burnt Jacket, the estimated growing season runs from 16 May to 1 October and from 2 May to 6 October, respectively (NRCS 1995). In the summer, both sites are moist and shaded, with low light.

Figure 6 shows the daily precipitation from May to September 2011 recorded at the Rangeley and Moosehead National Climatic Data Center weather observation stations (NCDC 2011). The Rangeley station is approximately 6 miles from the Saddleback boulder field and at an elevation $300 \mathrm{ft}$ lower than the boulder field. The Moosehead station is approximately 8 miles from the Burnt Jacket boulder field and is located at approximately the same elevation on the opposite shoreline of the lake. Both Saddleback and Burnt Jacket received consistently more precipitation in 2011 than in "normal" years. The NRCS has developed methods to interpret the historical climate record at weather stations and presents the results in a "WETS Table" (NRCS 1995). Table 1 provides the WETS analysis of the historical record at the NCDC weather observation stations at Rangeley and Moosehead and defines the normal range for monthly precipitation and growing season (NRCS 1995). Monthly precipitation is considered normal if it falls within the $30-70 \%$ range. These " $30 \%$ chance less than" and "30\% chance more than" thresholds are calculated from a fitted two-parameter gamma distribution (NRCS 1995). During the 2011 growing season, the precipitation at Rangeley was normal in May and June, below normal in July, and above normal in August and September. At Moosehead, the precipitation was normal for June and July and above normal in May, August, and September. The above-normal values in August and September are in large part attributable to two large storms that were remnants of tropical storms. 


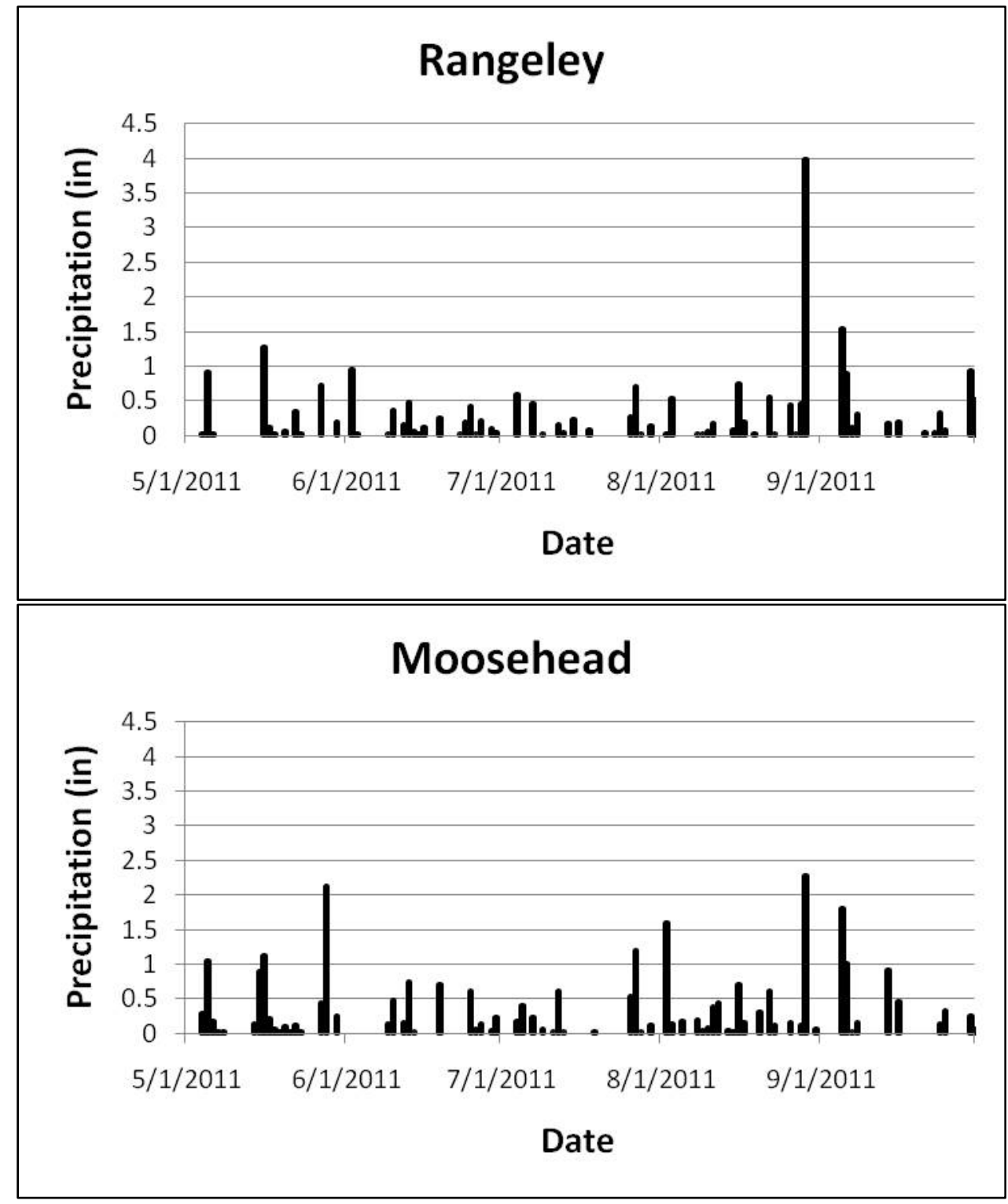

Figure 6. Daily precipitation from May-September 2011 at the Rangeley and Moosehead weather stations. The Rangeley station is located at $44^{\circ} 59^{\prime} \mathrm{N}, 70^{\circ} 40^{\prime} \mathrm{W}$ at $1530 \mathrm{ft}$ above sea level, and the Moosehead station is located at $45^{\circ} 35^{\prime} \mathrm{N}$, $69^{\circ} 43^{\prime} \mathrm{W}$ at $1028 \mathrm{ft}$ above sea level. 
Table 1. Summary of WETS table showing the average monthly precipitation, the $30 \%$ chance less than and more than thresholds, and the monthly precipitation for May-September 2011. The units are inches.

\begin{tabular}{|l|l|l|l|l|l|}
\hline \multirow{4}{*}{ Location } & Month & Average & $\begin{array}{l}30 \% \text { chance } \\
\text { less than }\end{array}$ & $\begin{array}{l}30 \% \text { chance } \\
\text { more than }\end{array}$ & $\begin{array}{l}2011 \\
\text { precipitation }\end{array}$ \\
\hline \multirow{7}{*}{ Rangeley } & May & 3.35 & 2.39 & 3.96 & 3.71 \\
\cline { 2 - 6 } & June & 4.03 & 3.06 & 4.7 & 3.41 \\
\cline { 2 - 6 } & July & 3.86 & 2.98 & 4.48 & 2.71 \\
\cline { 2 - 6 } & August & 3.99 & 2.72 & 4.76 & 7.36 \\
\cline { 2 - 6 } & September & 3.64 & 2.64 & 4.29 & 4.65 \\
\hline \multirow{5}{*}{ Moosehead } & May & 3.38 & 2.37 & 4.01 & 7.07 \\
\cline { 2 - 6 } & June & 4.11 & 3.24 & 4.73 & 3.31 \\
\cline { 2 - 6 } & July & 3.95 & 2.83 & 4.66 & 3.44 \\
\cline { 2 - 6 } & August & 3.81 & 2.7 & 4.51 & 7.59 \\
\cline { 2 - 6 } & September & 3.68 & 2.65 & 4.35 & 5.09 \\
\hline
\end{tabular}




\section{Methods}

\subsection{Well installation and data collection}

Using the well installation protocols described in the Technical Standard for Water-Table Monitoring of Potential Wetland Sites (USACE 2005) and Installing Monitoring Wells in Soils (Sprecher 2008), we installed three water table monitoring wells (hereafter referred to as "wells") on 17 May 2011 and two wells on 27 May 2011 at Saddleback. We installed 14 wells at Burnt Jacket on 26 May 2011. Owing to abundant, late-season snow cover throughout our field sites, we were not able to install the wells until a few weeks after the official start of the growing season, as determined by the WETS table.

Well placement was as random as possible, given the limitations associated with installing the wells between the 1 - to 4 -ft-wide boulders. Boulders were not removed for well installation because it might have altered the hydrology. Instead, we installed wells in the crevices between boulders. We scouted each site and found all the locations where it was possible to install a well. A stratified random design, which captured most of the topographic, pedologic, and hydrologic variation within the boulder fields, was used to place wells in two sample universes: locations with and without a separation between the folist layer and the soil surface (Fig. 7). The height of the separations varied from 6.0 in. $(15.2 \mathrm{~cm})$ to $12.5 \mathrm{in} .(31.8 \mathrm{~cm})$, and the thickness of the folist layer ranged from $2.0 \mathrm{in} .(5.0 \mathrm{~cm})$ to $8.7 \mathrm{in}$. $(22.0 \mathrm{~cm})$.

Where a separation between the folist layer and the mineral soil surface was observed, wells were randomly located in swales with and without hydric soils. In locations that lacked a separation of surfaces, wells were placed in swales with hydric and nonhydric soils and on mounds with nonhydric soils. No mounds were observed with hydric soils. Several locations in the boulder fields were not sampled because wells could not be installed. These included a separated surface over bare rock with water, a separated surface over bare rock with no water, and a thin, nonseparated surface over rock with no water. 

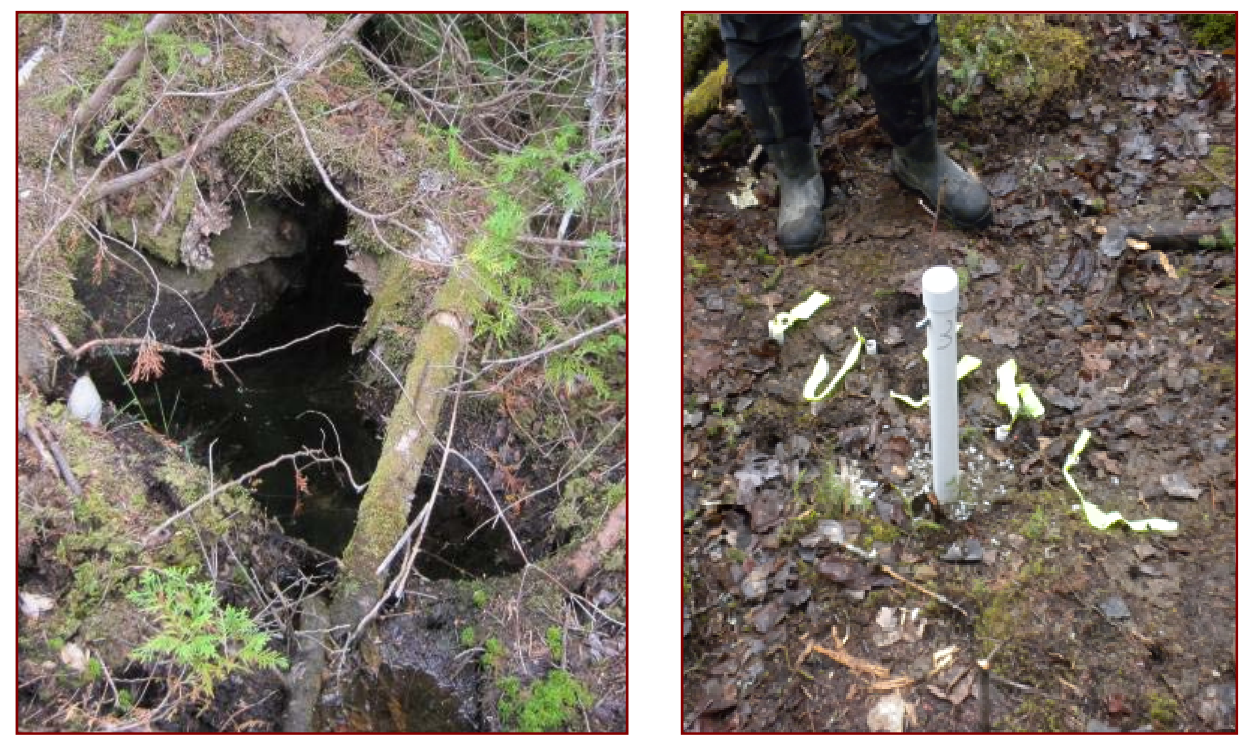

Figure 7. Sites with and without a separation between the folist layer and the soil surface. Left: Surfaces in which the moss and folist layer overlie the boulders and are separated from the soil surface, Burnt Jacket, Greenville, ME. Right: Monitoring well SB3, installed at a location that lacks a separation between the folist layer and the soil surface, Saddleback Mountain, Rangeley, ME.

Well holes were dug using a Dutch auger, and the excavated soil layers were used to develop a soil profile using standard wetland delineation descriptions and indicators (USACE 2009) and hydric soils criteria (NRCS 2010). The hue, value, and chroma of each layer were determined using Munsell Soil Color Charts (Gretag/Macbeth 2000). A summary of the soil profile for each well is included in Table 2.

The bottom few inches of each well hole was filled with silica sand. The well was placed in the hole such that the bottom screen was $15 \mathrm{in}$. below the soil surface. The PVC wells were $1.25 \mathrm{in}$. in diameter and $3 \mathrm{ft}$ tall with o.010-in. well screen at the bottom $12 \mathrm{in}$. of the well. The hole was filled with sand to $1 \mathrm{in}$. above the top of the well screen. The remaining space around the well was filled with bentonite chips. Water was added to the bentonite chips to allow them to expand and seal the well to ensure that the water depths measured in the well were not influenced by precipitation infiltrating from the ground surface. A small mound of a soil and bentonite chip mixture was placed around the well on the ground surface to prevent water from ponding. 
Table 2. Profile for each well describing the thickness of the folist layer, the thickness of the separated surface between the folist layer and mineral soil, the soil profile, and additional comments about the well characteristics. A complete profile was not completed during the 17 May 2011 well installation. Because of labelling methods, there is no well 4 or 9 at Burnt Jacket.

\begin{tabular}{|c|c|c|c|c|c|c|}
\hline Well & $\begin{array}{l}\text { Folist } \\
\text { thickness } \\
\text { (in.) }\end{array}$ & $\begin{array}{l}\text { Separated } \\
\text { thickness } \\
\text { (in.) }\end{array}$ & $\begin{array}{l}\text { Soil profile } \\
\text { depth (in.) }\end{array}$ & Soil profile matrix color & $\begin{array}{l}\text { Hydric soil } \\
\text { indicator }\end{array}$ & Additional comments \\
\hline SB1 & NR & 0 & N/A & 10YR 3/2 & None & Complete soil profile not recorded \\
\hline SB2 & NR & 0 & $\mathrm{~N} / \mathrm{A}$ & 10YR 3/2 & None & Complete soil profile not recorded \\
\hline SB3 & NR & 0 & $\mathrm{~N} / \mathrm{A}$ & 10YR 3/2 & None & Complete soil profile not recorded \\
\hline SB4 & 5 & 0 & $0-15$ & 10YR 3/1 & A4, F3 & \\
\hline \multirow[t]{2}{*}{ SB5 } & \multirow[t]{2}{*}{0} & \multirow[t]{2}{*}{0} & $0-0.5$ & Organic material & \multirow[t]{2}{*}{ F3 } & \\
\hline & & & $0.5-15$ & 10YR 3/1 & & \\
\hline \multirow[t]{2}{*}{ BJ1 } & \multirow[t]{2}{*}{0} & \multirow[t]{2}{*}{0} & $0-11$ & 7.5YR 2.5/2 (Organic muck) & \multirow[t]{2}{*}{$\mathrm{A} 2, \mathrm{~A} 4$} & \multirow[t]{2}{*}{ Open hole } \\
\hline & & & $11-15$ & 10YR 2/1 & & \\
\hline \multirow[t]{2}{*}{ BJ2 } & \multirow[t]{2}{*}{3} & \multirow[t]{2}{*}{0} & $0-2$ & 10YR 4/6 & \multirow[t]{2}{*}{ None } & \multirow{2}{*}{$\begin{array}{l}\text { Near clear-cut with a few downed trees; } \\
\text { more open exposure than other wells }\end{array}$} \\
\hline & & & $2-15$ & 10YR 4.1 & & \\
\hline \multirow[t]{3}{*}{ BJ3 } & \multirow[t]{3}{*}{5} & \multirow[t]{3}{*}{0} & $0-1$ & 10YR 5/1 (Spodic layer) & \multirow[t]{3}{*}{ None } & \\
\hline & & & $1-3$ & 10YR 3/4 & & \\
\hline & & & $3-15$ & 10YR 4/3 & & \\
\hline \multirow[t]{2}{*}{ BJ5 } & \multirow[t]{2}{*}{4} & \multirow[t]{2}{*}{4.5} & $0-2$ & Organic muck & \multirow[t]{2}{*}{ A10 } & \\
\hline & & & $2-15$ & 10YR 4/1 & & \\
\hline \multirow[t]{2}{*}{ BJ6 } & \multirow[t]{2}{*}{3} & \multirow[t]{2}{*}{0} & $0-1$ & 10YR 4/1 (Spodic layer) & \multirow[t]{2}{*}{ None } & \\
\hline & & & $1-15$ & 10YR 3/2 & & \\
\hline \multirow[t]{2}{*}{ BJ7 } & \multirow[t]{2}{*}{4} & 0 & $0-1$ & 10YR 5/1 (Spodic layer) & None & \\
\hline & & & $1-15$ & 10YR 3/2 & & \\
\hline BJ8 & 5 & 0 & $0-15$ & 10YR 5/1 & F3 & \\
\hline BJ10 & 6 & 0 & $0-15$ & 10YR 4/1 & None & Observe water filling hole at base \\
\hline BJ11 & 5 & 8 & $0-10$ & 10YR 2/2 (Muck) & $\mathrm{A} 2, \mathrm{~A} 4$ & \\
\hline & & & $10-11$ & 10YR 3/2 & & \\
\hline & & & $11-15$ & 10YR 4/2 & & \\
\hline BJ12 & 3 & 0 & $0-4$ & 10YR 4/6 & None & \\
\hline & & & $4-6$ & 2.5YR 5.6 & & \\
\hline & & & $6-15$ & 2.5YR 5/4 & & \\
\hline BJ13 & 0 & 0 & $0-15$ & Sapric muck, sulfur smell & $\mathrm{A} 1, \mathrm{~A} 4$ & $\begin{array}{l}\text { Close to clear-cut forest edge; } \\
\text { influenced by extra light }\end{array}$ \\
\hline BJ14 & 4 & 0 & $0-4$ & 10YR 5/6 & F3 & \\
\hline & & & $4-15$ & 10YR 5/1 with mottles 10YR 6/6 & & \\
\hline BJ15 & 5 & 10 & $0-5$ & Folist layer & A1, A4 & No soil development in this hole; well \\
\hline & & & $5-15$ & Sapric muck over rock & & $\begin{array}{l}\text { installed so top of folist lined up with top } \\
\text { of well screen }\end{array}$ \\
\hline BJ16 & 8 & 4 & $0-1$ & 10YR 3/2 & None & Gravel mixed in with silty clay loam \\
\hline & & & $1-9$ & Gravel & & \\
\hline & & & $9-15$ & 10YR 4/1 & & \\
\hline
\end{tabular}


A Levelogger was installed in each well, and the water depth was recorded every 15 minutes. We installed a Barologger in one well at Saddleback and Barologgers in two wells at Burnt Jacket. We followed recommended protocol in the Levelogger User Guide (Solinst 2010) to determine the water level using the Solinst Levelogger Gold, Solinst Barologger Gold, and the Solinst Version 3.4.o Software. When submerged, the Levelogger records the total pressure and reports the temperature-adjusted pressure readings as the water level. To determine the actual water level, two data corrections must be applied using the Solinst Version 3.4.o Software. The first correction uses the Barologger data to account for changes in the atmospheric pressure. Because we had two Barologgers at Burnt Jacket, we adjusted the data using the Barologger closest to each well. The second correction was to adjust the water level to a reference datum for each well. This was determined by manually measuring the actual water depth in the well.

We collected manual water depth measurements in July, August, and October for each time we downloaded the Levelogger data. In July and October, we observed where the water line occurred on a tape measure and stick, respectively. For the August sampling, we drew a line using a washable marker on a tape measure and recorded the position where the marker was washed away. However, when we applied each month's manual adjustment to the dataset, we noticed that the data shift between manual sampling months often disagreed by a couple of inches. For example, the last datalogger recording in our May-July sampling period may have been -5 in. However, the first datalogger recording from July to August, typically within 1 hour of the last measurement, may have been -8 in., suggesting an unnaturally quick drop of 3 in. in 1 hour. There were no trends indicating that one measuring method showed consistently higher or lower water levels. This implied that our manual method was not very accurate, as typical decreases in water levels during a 1-hour period were often only a fraction of an inch. We plotted the variation between different manual measurements to show the potential range of water levels for each well. We noted where this variation resulted in significant change to the hydrology output. For consistency, we present the results using the August adjustment for all wells.

\subsection{Documenting wetland indicators}

Wetland hydrology indicators, hydric soil indicators, and vegetation data were recorded on 6-7 July 2011. All variables were measured in 6.6- $\times 6.6-$ $\mathrm{ft}$ plots to minimize within-plot variation. In each plot, the separation be- 
tween the folist layer (O layer) and the mineral soil surface (A layer) was measured and recorded. We used a Dutch auger to take a soil core from five random locations. Core locations were limited by within-plot microtopographic variation and the presence of large boulders. Cores were located adjacent to and in the same topographic position (swale or mound) as the well.

The five soil cores were tested using alpha,alpha-dipyridyl (AAD) liquid and AAD paper strips to document primary hydrology indicator $\mathrm{C}_{4}$ (the presence or absence of ferrous iron) in each plot (USACE 2009; NRCS 2012). Because of the heavy rainfall, all soils were moist, saturated, or inundated when AAD testing occurred. The AAD liquid was kept refrigerated and out of direct sunlight. It was applied directly to freshly broken, saturated peds from the top 12 in. of the soil surface in five random locations in each plot. If three or more soil samples from a plot turned red or reddish-pink, the soils were determined to contain reduced iron. The AAD paper strips were wetted with a drop of dilute $\mathrm{HCl}$ solution. Each wetted strip was rubbed with a freshly broken ped from each of the five random locations in each plot. If three or more of the AAD paper strips from a plot turned red or reddish-pink, then soils were determined to contain reduced iron, yielding a positive primary indicator of wetland hydrology.

IRIS tubes (PVC tubes coated with iron oxyhydroxide paint) were used to determine if reducing conditions were present in boulder field soils. IRIS tubes were obtained from InMass Technology, West Lafayette, IN, and were installed on 26-27 May 2011 and removed after the end of the growing season on 19-20 October 2011. IRIS tubes were installed in each plot at five random locations within the $6.6-\times 6.6-\mathrm{ft}$ plots. Tubes were located adjacent to the well and as close to the same topographic position (swale or mound) as the boulders allowed. Tubes were air dried, and visual estimates of the percentage of the PVC surface where oxidized iron was completely removed or significantly yellowed were recorded. Soils were considered anaerobic if three of the five IRIS tubes in a plot showed removal or significant yellowing of $30 \%$ or more of the oxidized iron coating in a 6in.-long zone (Berkowitz 2009), thus meeting the definition of a hydric soil.

Variations in vegetation structure, diversity, and spatial arrangement exist on the landscape that are not addressed in the sampling approach presented in NC-NE RS (USACE 2009). In wet boulder fields, environmental 
variation occurred at two spatial scales. Topographic, pedologic, and hydrologic variation in the boulder fields occurred at a small scale, and variation in the plant community occurred at a landscape scale. To capture this variation, we used small plots to document variation in soils and hydrology. But to accurately document the presence or absence of hydrophytic vegetation, we visually estimated the percent cover of all vascular plant species rooted in or overtopping the plots, representing the larger community scale. Because very few plants were rooted in the small plots, we included vegetation that overtopped the plot, in order to better represent the plant community. Vascular plants were identified according to Gleason and Cronquist (1991), and nomenclature followed Kartesz (2009). The percent cover of all bryophytes growing on rocks, on mounds, or in hollows was also recorded.

\subsection{Calculating the PI, the DR, and the FN-DR}

To calculate the Prevalence Index (PI), we used percent cover data from the 6.6- $\times 6.6-\mathrm{ft}$ plots and the following formula:

$$
\mathrm{PI}=\left(\mathrm{S}_{\mathrm{obl}}+2 \mathrm{~S}_{\mathrm{facw}}+3 \mathrm{~S}_{\mathrm{fac}}+4 \mathrm{~S}_{\mathrm{facu}}+5 \mathrm{~S}_{\mathrm{upl}}\right) /\left(\mathrm{S}_{\mathrm{obl}}+\mathrm{S}_{\mathrm{facw}}+\mathrm{S}_{\mathrm{fac}}+\mathrm{S}_{\mathrm{facu}}+\mathrm{S}_{\mathrm{upl}}\right)
$$

where $\mathrm{S}$ is the summed abundance. In each plot, we summed the absolute abundance of each species across strata. Each species' total abundance was multiplied by its wetland indicator status rating, a value ranging from 1 (OBL) to 5 (UPL). The regional wetland indicator statuses of all plant species were obtained from the National List of Plant Species that Occur in Wetlands (Reed 1988). These values were summed and then divided by the total abundance of all species. Vegetation in plots with PI values less than or equal to 3.0 was considered hydrophytic. Vegetation in plots with PI values greater than 3.0 was considered nonhydrophytic (USACE 2009).

We calculated the Dominance Ratio (DR) using the wetland indicator status of the dominant plant species in each stratum and instructions in the COE Manual (Environmental Laboratory 1987). A vegetative stratum was considered present if it constituted at least $5 \%$ of the plot's total cover. In each stratum, dominant plant species were determined using the 50/20 approach. Plant species were ranked in descending order by absolute abundance values, and the 50 and $20 \%$ thresholds were determined by multiplying the stratum's total cover by 50 and $20 \%$, respectively. If a single species exceeded the $50 \%$ threshold, that species was considered dominant. When no species exceeded the $50 \%$ threshold, dominant species 
were those selected from the top of this list until their cumulative abundance exceeded the 50\% threshold. In addition, if any species had an absolute abundance value greater than or equal to the $20 \%$ threshold and had not yet been selected, it was also considered dominant. Species with equal abundance values were treated equally as dominants or nondominants. Species with indicator status ratings of OBL, FACW, or FAC were considered hydrophytes. To determine the percentage of hydrophytic vegetation in the plot, we summed the dominant hydrophytes from each of the strata, divided by the summed total of all dominant species, and multiplied by 100. Vegetation in plots with DR values greater than 50.0\% was considered hydrophytic. Vegetation in plots with DR values less than or equal to $50.0 \%$ was considered nonhydrophytic (Environmental Laboratory 1987; USACE 2009).

The FAC-neutral Dominance Ratio (FN-DR), which was used as a secondary indicator of hydrology (FAC-Neutral Test), was calculated using the DR procedure described above, except that FAC species were treated as null. To determine the percentage of OBL and FACW vegetation in the plot, we summed the dominant species from each of the strata with an OBL or FACW indicator status rating; divided by the summed total of all dominant species with an OBL, FACW, FACU, or UPL indicator status rating; and multiplied by 100. Plots with FN-DR values greater than $50.0 \%$ were considered to pass the FAC-Neutral Test, a secondary indicator of wetland hydrology. Plots with FN-DR values less than 50.0\% were considered to fail the FAC-Neutral Test. If exactly $50.0 \%$ of the dominant vegetation was OBL and/or FACW, the determination was made using the previously described procedure on the nondominant plant species (Environmental Laboratory 1987, USACE 2009).

It is important to note that previous work has demonstrated that PI, DR, and FN-DR values may not always accurately determine whether or not a plant community is hydrophytic. There are several reasons for these discrepancies. For instance, the DR exhibits an odd-hydrophytic/evennonhydrophytic bias based on whether the number of dominants is odd or even in a plot (Lichvar et al. 2011). The presence of a low-cover stratum can also bias DR determinations (Gillrich et al. 2011). The PI can also exhibit a nonhydrophytic bias when plots are composed mainly of FACU and FAC species (Lichvar, unpublished data). Therefore, we used these vegetation indices with caution, particularly when the vegetation was dominated by FACU species. 


\subsection{Statistical analysis}

Two types of statistical tests were performed: quantitative, which tested the wetland hydrology criterion and the percentage of moss cover, and categorical, which tested indicators from the NC-NE RS (USACE 2009) and the separated surface. To test the wetland hydrology criterion, we divided the 19 plots into two groups based on the groundwater monitoring results: plots that met the wetland hydrology criterion of a water table within the top $12 \mathrm{in}$. of the soil surface for 14 or more consecutive days during the growing season vs. plots that failed to meet that criterion (USACE 2005). To determine whether the average height of the water table differed between the two groups, we tested the median water table height for the plots in each group. To determine whether there was a significant difference in the duration of wetland hydrology, we tested the total number of consecutive days that the water table was within $12 \mathrm{in}$. of the soil surface in each group of plots. To determine if moss cover was greater in plots that met the wetland hydrology criterion, we tested differences in the median percentage of moss cover in each group of plots. Shapiro-Wilk and Anderson-Darling normality tests for the total consecutive days data $(\mathrm{p}=0.03 \mathrm{O}$, $\mathrm{p}=0.029)$, the median water table $(\mathrm{p}=0.028, \mathrm{p}=0.024)$, and the moss cover data $(\mathrm{p}=0.017, \mathrm{p}=0.019)$ indicated that none had a normal distribution. Mann-Whitney tests, which are nonparametric tests that compare medians when data are non-normally distributed or the sample size is small (Moore and McCabe 2002), were used for these three comparisons.

To examine agreement between the wetland hydrology criterion and vegetation, soil, and hydrology indicators, we calculated the proportion of plots in which the criterion was met and the indicators were present. We calculated the proportion of plots that met the wetland hydrology criterion of a water table within the top $12 \mathrm{in}$. of the soil surface for 14 or more consecutive days during the growing season vs. plots that failed to meet that criterion (USACE 2005). We calculated the proportion of plots that contained either at least one primary or at least two secondary hydrology indicators described in the NC-NE RS (USACE 2009). We also calculated the proportions of plots that met primary hydrology indicator $\mathrm{C}_{4}$, soils that contained ferrous iron, as determined by $\mathrm{AAD}$ paper strips or $\mathrm{AAD}$ liquid. The proportion of plots that contained hydric soils was calculated using the field indicators described in the NC-NE RS (USACE 2009). The proportion of plots in which soils were anaerobic was determined based on IRIS tube reduction. We calculated the proportion of plots that were characterized by a separation between the folist layer and the mineral soil surface. The 
proportion of plots that contained hydrophytic vegetation based on PI and DR calculations was also determined. Finally, we calculated the proportion of plots that met the NC-NE RS criteria for a FACU-dominated wetland.

We used Fisher's exact tests to determine whether differences among the proportions were significant. Fisher's exact tests are designed for use with categorical data, similar to the Chi-Square test of association. However, they are not based on the assumption of a large sample size. Instead of calculating a test statistic using the observed and expected values for each category, as the Chi-Square test does, Fisher's exact tests calculate a test statistic by counting all possible outcomes exactly, including interactions greater than and less than those actually observed. Fisher's exact tests are more conservative and have greater statistical power than a Chi-Square test because they are less likely to reject a null hypothesis when it is true (Bowman and Shetty 2007). SYSTAT 12 statistical software (SYSTAT 2007) was used to perform all tests.

\subsection{Boulder field delineation}

To develop a method for delineating wet boulder fields, we used vegetation, soil, and hydrology indicators, including the well data, for each plot, and the wetland delineation methods described in the NC-NE RS (USACE 2009), to divide the plots into four categories: uplands, three-factor wetlands, FACU-dominated wetlands, and FACU-dominated wetlands with problematic soils.

A plot was determined to be located in a three-factor wetland if it contained one primary indictor of hydrology, one hydric soil indicator from the NC-NE RS, and vegetation that had either a DR value greater than $50.0 \%$ or a PI value less than or equal to 3.0.

Plots that contained fewer than three factors and failed the AAD paper strips test, which showed that the primary hydrology indicator $\mathrm{C}_{4}$ was absent, were considered to be located in uplands.

If a plot contained fewer than three factors and passed the $\mathrm{AAD}$ paper strips test, we tested the vegetation to determine if the plot met the requirement for a FACU wetland. We dropped two FACU species, Pinus strobus (L.) and Picea rubens (Sarg.), which commonly dominate wetlands in the NC-NE region, from the data according to the suggested methods described in the regional supplement. Both vegetation indices 
were recalculated. If either formula indicated that the plot met the hydrophytic vegetation criterion after these species were dropped, then the plot was determined to be located in a FACU-dominated wetland (USACE 2009).

To determine if a FACU-dominated wetland with problematic soils was present, we verified that the vegetation was dominated by hydrophytic, though FACU, species, as described above. Then we verified that at least one primary wetland hydrology indicator was present and that the plots were located in a landscape area likely to collect or concentrate water. $\mathrm{Hy}-$ dric soil determinations were made based on the definition of a hydric soil and the results of the reactions of AAD paper strips and IRIS tube reduction. 


\section{Results}

\subsection{Water table levels}

The well data (Table 3 ) show that 12 of the 19 wells (63\%) met the wetland hydrology criterion of water levels within 12 in. of the surface for 14 consecutive days or more during the growing season monitoring period. Five of the wells met the wetland hydrology criterion $100 \%$ of the time. Two of the 19 wells were clearly upland sites, with water within 12 in. of the surface for less than a day at a time in direct response to a precipitation event.

Table 3. Summary of the water table monitoring throughout the growing period as adjusted using the Barologgers and August manual measurement. The ground surface is assumed to be a water depth of 0 . Negative values are the depth of the water table from the ground; positive values indicate surface ponding. The consecutive days are the number of days in a row during which the water depth met the wetland hydrology criterion. The \% days is the proportion of time over the entire monitoring period during which the water depth met the wetland hydrology criterion.

\begin{tabular}{|l|r|r|r|r|r|}
\hline \multirow{2}{*}{ Well } & \multicolumn{2}{|c|}{ Water table depth (in.) } & \multicolumn{3}{c|}{ Days in which wetland hydrology criterion met } \\
\cline { 2 - 6 } & Mean & Median & Consecutive & \multicolumn{1}{c|}{ Total } & \multicolumn{1}{c|}{$\%$} \\
\hline SB1 & -15.43 & -16.41 & 3.75 & 17.47 & 12.71 \\
\hline SB2 & -15.62 & -16.38 & 2.57 & 9.59 & 6.98 \\
\hline SB3 & -15.97 & -16.43 & 1.69 & 4.79 & 3.49 \\
\hline SB4 & -1.00 & -2.22 & 127.44 & 127.44 & 100.00 \\
\hline SB5 & -8.12 & -9.61 & 47.97 & 88.44 & 69.39 \\
\hline BJ1 & -0.14 & 0.75 & 132.97 & 132.97 & 100.00 \\
\hline BJ2 & -14.47 & -14.39 & 1.53 & 5.04 & 3.79 \\
\hline BJ3 & -12.44 & -12.54 & 9.78 & 55.03 & 41.33 \\
\hline BJ5 & -4.16 & -3.63 & 66.21 & 125.82 & 94.53 \\
\hline BJ6 & -10.21 & -9.53 & 46.16 & 96.06 & 72.15 \\
\hline BJ7 & -9.02 & -8.50 & 46.19 & 119.25 & 89.56 \\
\hline BJ8 & -11.38 & -10.44 & 45.89 & 90.52 & 67.99 \\
\hline BJ10 & -12.45 & -12.37 & 15.36 & 53.70 & 40.34 \\
\hline BJ11 & 7.62 & 8.16 & 132.97 & 132.97 & 100.00 \\
\hline BJ12 & -16.46 & -15.55 & 0.45 & 1.10 & 0.83 \\
\hline BJ13 & -0.60 & -0.53 & 133.15 & 133.15 & 100.00 \\
\hline BJ14 & -16.55 & -16.57 & 0.05 & 0.08 & 0.06 \\
\hline BJ15 & -11.60 & -11.47 & 32.20 & 79.46 & 59.78 \\
\hline BJ16 & -1.59 & -2.13 & 132.93 & 132.93 & 100.00 \\
\hline
\end{tabular}


To see if the potential errors in the manual measurement of the water level changed whether or not a well met the wetland hydrology criterion, we plotted the water levels for each well with adjustments based on each of the three manual measurements. Only Burnt Jacket Well 3 was affected (Fig. 8); for all other wells, the variation in adjustment impacted only the percentage of total time that the water level was above or below $12 \mathrm{in}$. but not whether or not the well met the wetland hydrology criterion. Figure 8 shows that, for Burnt Jacket Well 3, the water level did not meet the wetland hydrology criterion when we used the August and October adjustments. However, for the July shift, the wetland criterion was met, with water levels within 12 in. for 40.1 consecutive days. Regardless, we have some concern about this well because, for all the adjustments, the lowest water depth was more than 20 in. below the ground surface. If this well had been properly installed according to our protocol, our maximum water depth should be 15 in., the depth of the well below the ground surface. Although the water level follows the general trends of the other wells at Burnt Jacket, with increases after precipitation events and decreases during dry periods, the particular water depth values are questionable and may be ascribable to an error in the Levelogger calibration.

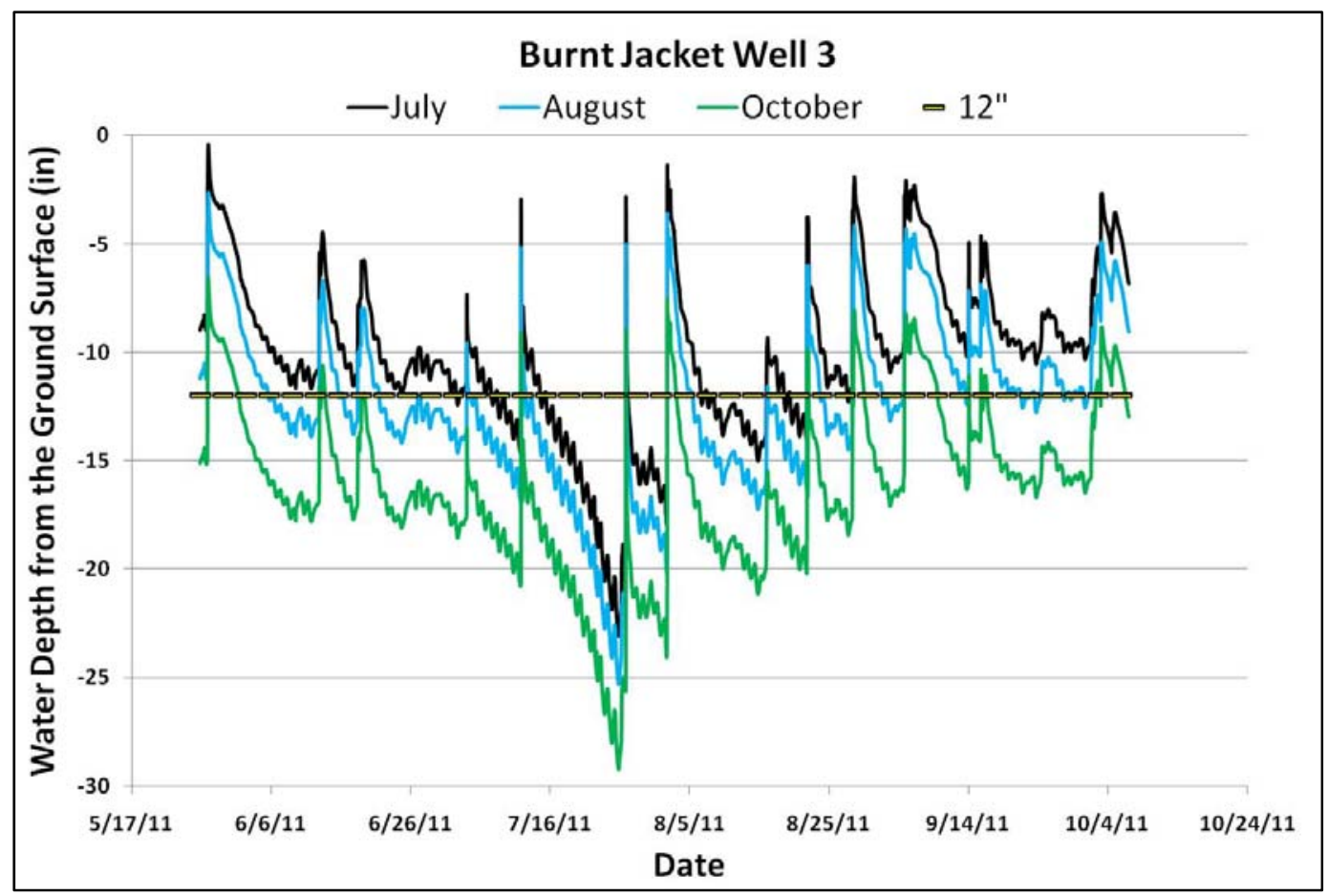

Figure 8. Shift adjustment using the manual measurement from each month. 


\subsection{Statistical analysis}

Mann-Whitney tests suggested that the median water table was significantly higher $(\mathrm{p}<0.001)$ in plots that met the wetland hydrology criterion $(-6.065$ in.) than in plots that failed to meet the wetland hydrology criterion $(-16.380$ in.) (Table 4$)$. The water table was also within the top 12 in. of the soil surface for a significantly larger number of consecutive days ( $\mathrm{p}<0.001$ ) in plots that met the wetland hydrology criterion (57 days) than in plots that failed to meet the wetland hydrology criterion (2 days). However, the median moss cover in plots that met the wetland hydrology criterion (91.5\%) was not significantly different from the median moss cover (65.0\%) in plots that did not meet the criterion ( $\mathrm{p}=0.107)$, suggesting that there is no association between total moss cover and the presence of wetland hydrology in these wet boulder fields.

Fisher's exact tests showed that the wetland hydrology criterion was associated with the presence of hydric soils, the presence of ferrous iron in soils, FACU-dominated wetlands, and a separation between the folist layer and the soil surface. The proportion of all plots that contained hydric soil indicators according to the NC-NE RS (0.474) or based on IRIS tube reduction (0.684) was not significantly different from the proportion of all plots that met the wetland hydrology criterion (0.632) $(\mathrm{p}=0.515, \mathrm{p}=1.00)$ (Table 5). The proportion of all plots characterized by a separation between the folist layer and the soil surface was also not significantly different from those that met the hydrology criterion (0.368) ( $\mathrm{p}=0.194)$. Likewise, the proportions of plots that contained soils with ferrous iron as determined by AAD strips (0.579) and AAD liquid (0.526) were not significantly different from the proportion of plots that met the wetland hydrology criterion $(\mathrm{p}=1.00, \mathrm{p}=0.743)$. The proportion of plots that met the wetland hydrology criterion was not significantly different from the proportion of all plots that qualified as FACU-dominated wetlands (0.474) $(\mathrm{p}=0.515)$ (Table 4). There was also no significant difference in the proportion of all plots that contained hydric soil indicators according to the NCNE RS and the proportion of all plots characterized by a separation between the folist layer and the soil surface $(\mathrm{p}=0.743)$. 
Table 4. Results from Mann-Whitney tests comparing medians and Fisher's exact tests comparing proportions of soil indicators in all plots. $\dot{p}$ represents the proportion of all plots in which a variable was present. Significance is marked as: $* *$ for $p<0.01$

\begin{tabular}{|l|l|l|}
\hline \multicolumn{2}{|l|}{ Hypotheses for Mann-Whitney tests } & $p$-value \\
\hline 1 & $\begin{array}{l}\text { Median water table height in plots that met wetland hydrology criterion = median water } \\
\text { table height in plots that did not meet wetland hydrology criterion }\end{array}$ & $<0.001^{* *}$ \\
\hline 2 & $\begin{array}{l}\text { Number of consecutive days that water table height was } \geq-12.0 \text { in. in plots that met } \\
\text { wetland hydrology criterion = number of consecutive days that water table height was } \\
\geq-12.0 \text { in. in plots that did not meet wetland hydrology criterion }\end{array}$ & $<0.001^{* *}$ \\
\hline 3 & $\begin{array}{l}\text { Percentage of moss cover in plots that met wetland hydrology criterion = percentage of } \\
\text { moss cover in plots that did not meet wetland hydrology criterion }\end{array}$ & 0.107 \\
\hline Hypothesis for Fisher's exact tests & $\begin{array}{l}\tilde{p} \text { of all plots that met the wetland hydrology criterion = ṕ of all plots that contain FACU } \\
\text { dominated wetland }\end{array}$ & 0.515 \\
\hline 4 & $\tilde{p}$ of all plots with a separated folist layer = $\not$ of all plots with NC-NE hydric soil indicators & 0.743 \\
\hline
\end{tabular}

However, the data suggest that in wet boulder fields there is no meaningful association between plots that met the wetland hydrology criterion and the hydrology indicators from the NC-NE RS. The proportion of all plots that contained either at least one primary or at least two secondary field indicators of wetland hydrology (0.947) was significantly larger than the proportion of plots that met the wetland hydrology criterion based on the groundwater data (o.632) $(\mathrm{p}=0.042)$ (Table 5). Likewise, the proportion of all plots that met the wetland hydrology criterion based on the groundwater data was significantly larger than the proportion of all plots that contained hydrophytic vegetation, as determined by the Dominance Ratio (o.211) $(\mathrm{p}=0.020)$ or the Prevalence Index (o.263) $(\mathrm{p}=0.049)$. 
Table 5. Results of Fisher's exact tests comparing the proportion of plots that met the wetland hydrology criterion with the proportion of plots that contained indicators of wetland hydrology, hydric soils, and hydrophytic vegetation described in the Northcentral-Northeast Regional Supplement (NC-NE RS) (USACE 2009). The shaded data are for plots that met the wetland hydrology criterion for delineations: groundwater within the top 12 in. of the soil surface for 14 or more consecutive days during the growing season. Letter/number combinations refer to indicator descriptors in the NC-NE RS. $P=$ present. $A=$ absent. $\quad$ represents the proportion of all plots in which an indicator was present. Significance is marked as: * for $p<0.05$ and $* *$ for $p<0.01$

\begin{tabular}{|c|c|c|c|c|c|c|c|c|c|c|}
\hline & \multicolumn{2}{|c|}{$\begin{array}{l}\text { Wetland hydrology } \\
\text { criterion }\end{array}$} & \multicolumn{3}{|c|}{ NC-NE RS hydrology indicators } & \multicolumn{3}{|c|}{ NC-NE RS soil indicators } & \multicolumn{2}{|c|}{ NC-NE RS vegetation indicators } \\
\hline & \multirow{2}{*}{$\begin{array}{c}\text { Total } \\
\text { consecutive } \\
\text { days within } \\
12 \text { in. }\end{array}$} & \multirow{2}{*}{$\begin{array}{l}\text { Median } \\
\text { height } \\
\text { (in.) }\end{array}$} & \multirow[b]{2}{*}{$\begin{array}{l}\text { Primary and secondary hydrology } \\
\text { indicators }\end{array}$} & \multicolumn{2}{|c|}{ Alpha,alpha-dipyridyl } & \multirow[b]{2}{*}{$\begin{array}{c}\text { Soil } \\
\text { indicators }\end{array}$} & \multirow[b]{2}{*}{$\begin{array}{l}\text { IRIS } \\
\text { tubes }\end{array}$} & \multirow[b]{2}{*}{$\begin{array}{l}\text { Separated } \\
\text { surface }\end{array}$} & \multirow[b]{2}{*}{$\begin{array}{l}\text { Prevalence } \\
\text { Index }\end{array}$} & \multirow[b]{2}{*}{ Dominance Ratio } \\
\hline & & & & $\begin{array}{l}\text { Strips } \\
\left(1^{\circ}-\mathrm{C} 4\right)\end{array}$ & $\begin{array}{l}\text { Liquid } \\
\left(1^{\circ}-\mathrm{C} 4\right)\end{array}$ & & & & & \\
\hline BJ2 & 1.53 & -14.39 & A3, D2, D4-5 & $0 / 5$ & $1 / 5$ & & $5 / 5$ & A & 2.57 & 75.00 \\
\hline BJ3 & 9.78 & -12.54 & A3, D2, D4 & $2 / 5$ & $4 / 5$ & & $5 / 5$ & A & 2.98 & 40.00 \\
\hline BJ12 & 0.00 & -15.55 & D2, D4 & $0 / 5$ & $0 / 5$ & & $0 / 5$ & A & 3.50 & 0.00 \\
\hline BJ14 & 0.00 & -16.57 & $\mathrm{D} 2, \mathrm{D} 4$ & $0 / 5$ & $0 / 5$ & F3 & $0 / 5$ & A & 3.67 & 50.00 \\
\hline SB1 & 3.75 & -16.41 & & $0 / 5$ & $0 / 5$ & & $2 / 5$ & A & 2.64 & 50.00 \\
\hline SB2 & 2.57 & -16.38 & B8, D4 & $0 / 5$ & $0 / 5$ & & $0 / 5$ & A & 3.91 & 0.00 \\
\hline SB3 & 1.69 & -16.43 & B8, D2, D4 & $0 / 5$ & $0 / 5$ & & $0 / 5$ & A & 3.80 & 50.00 \\
\hline BJ8 & 45.89 & -10.44 & D2, D4 & $2 / 5$ & $3 / 5$ & F3 & $1 / 5$ & A & 3.13 & 66.67 \\
\hline BJ11 & 132.97 & 8.16 & A1-3, C1, C7, D2, D4-5 & $4 / 5$ & $5 / 5$ & $\mathrm{~A} 2, \mathrm{~A} 4$ & $5 / 5$ & $\mathrm{P}$ & 2.63 & 66.67 \\
\hline SB5 & 47.97 & -9.61 & A1-A3, B2-3, B8, B9, C7, D2, D4-5, B10 & $3 / 5$ & $3 / 5$ & F3 & $5 / 5$ & $\mathrm{P}$ & 2.51 & 80.00 \\
\hline BJ5 & 66.21 & -3.63 & A3, D2, D4 & $3 / 5$ & $1 / 5$ & $\mathrm{~A} 10$ & $5 / 5$ & $P$ & 3.60 & 0.00 \\
\hline BJ13 & 133.15 & -0.53 & A1-3, C1, C7, D2, D4-5 & $5 / 5$ & $5 / 5$ & A1, A4 & $5 / 5$ & A & 3.43 & 50.00 \\
\hline BJ15 & 32.20 & -11.47 & $\mathrm{~A} 1-3, \mathrm{~B} 2-3, \mathrm{~B} 9, \mathrm{C} 1, \mathrm{C} 7, \mathrm{D} 2, \mathrm{D} 4$ & $3 / 5$ & $0 / 5$ & A1, A4 & $3 / 5$ & $\mathrm{P}$ & 3.53 & 40.00 \\
\hline SB4 & 127.44 & -2.22 & A1-3,B3, B8, C1, C7, D2, D4, B10, B16 & $5 / 5$ & $5 / 5$ & $\mathrm{~A} 4, \mathrm{~F} 3$ & $5 / 5$ & $\mathrm{P}$ & 3.11 & 50.00 \\
\hline BJ16 & 132.93 & -2.13 & A1-A3, D2, D4 & $4 / 5$ & $3 / 5$ & & $5 / 5$ & $\mathrm{P}$ & 4.00 & 0.00 \\
\hline BJ1 & 132.97 & 0.75 & A1-3, C1, D2, D4 & $5 / 5$ & $3 / 5$ & $\mathrm{~A} 2, \mathrm{~A} 4$ & $5 / 5$ & $\mathrm{P}$ & 3.84 & 20.00 \\
\hline BJ6 & 46.16 & -9.53 & D2, D4 & $5 / 5$ & $5 / 5$ & & $5 / 5$ & A & 3.80 & 25.00 \\
\hline BJ7 & 46.19 & -8.50 & A3, D2, D4 & $4 / 5$ & $4 / 5$ & & $5 / 5$ & A & 3.95 & 0.00 \\
\hline BJ10 & 15.36 & -12.37 & D2, D4 & $4 / 5$ & $1 / 5$ & & $4 / 5$ & A & 3.99 & 50.00 \\
\hline$p^{\prime}$ & \multicolumn{2}{|l|}{0.632} & 0.947 & 0.579 & 0.526 & 0.474 & 0.684 & 0.368 & 0.263 & 0.211 \\
\hline$p$ value & \multicolumn{2}{|l|}{$\mathrm{n} / \mathrm{a}$} & $p=0.042 *$ & $p=1.00$ & $p=0.743$ & $p=0.515$ & $p=1.00$ & $p=0.194$ & $p=0.049 *$ & $p=0.020 *$ \\
\hline
\end{tabular}




\subsection{Boulder field delineation}

Three of the 19 plots (BJ11, SB5, and BJ8) were determined to be located in three-factor wetlands, based on the presence of one primary indicator of hydrology, including the groundwater monitoring data, at least one hydric soil indicator, and hydrophytic vegetation (DR $>50.0 \%$ or PI $\leq 3.0$ ) (Table 6). Seven of the 19 plots were determined to be located in uplands, because they lacked at least one of the three wetland delineation factors and failed to meet hydrology indicator $\mathrm{C}_{4}$ (presence of reduced iron). In these plots almost none of the paper strips exhibited a positive reaction to AAD (Table $5)$.

Six plots (BJ1, BJ5, BJ13, BJ15, BJ16, and $\mathrm{SB} 4$ ) were determined to be located in FACU-dominated wetlands (Table 6). In these plots NC-NE RS primary hydrology and hydric soil indicators were present but Picea rubens and Pinus strobus were the dominant plant species. Three of the six plots contained hydrophytic vegetation once these FACU dominants were removed. The remaining three plots were determined to be located in FACU-dominated wetlands for one of three reasons: 1) bias in the PI formula (Lichvar, unpublished data) obscured the nature of the plant community, which was $94.4 \%$ hydrophytic (SB4); 2) once the FACU dominant was removed, cover was so sparse $(<0.1 \%)$ that the vegetation indices were meaningless (BJ16); or 3) the small plot size artificially inflated the abundance of a FACU species (Acer spicatum Lam.) that was not dominant in the entire community (BJ1).

Three plots (BJ6, BJ7, and BJ10) were determined to be located in FACUdominated wetlands with problematic soils (Table 6). These plots met the hydrophytic vegetation requirement for a FACU-dominated wetland but did not display any of the hydric soil indicators described in the NC-NE RS. In all of these plots at least four out of five IRIS tubes reduced, and four out of five ADD paper strips reacted positively (Table 5). 
Table 6. Summary results showing method used to classify plots into one of four categories for delineation purposes: uplands, three-factor wetlands, FACU-dominated wetlands, and FACU-dominated wetlands with problematic soils. Determinations were made using the wetland indicators and procedures described in the NC-NE RS (USACE 2009). Primary hydrology indicators include the ground water monitoring data. $\mathrm{H}=$ primary indicator of wetland hydrology, $\mathrm{S}=$ hydric soils, and $\mathrm{V}=$ hydrophytic vegetation. Plots marked with an asterisk were determined to be FACU-dominated wetlands based on documented bias associated with vegetation formulas (Lichvar et al. 2011; Gillrich et al. 2011; Lichvar, unpublished) and best professional judgment.

\begin{tabular}{|c|c|c|c|c|c|c|c|c|}
\hline \multirow[b]{2}{*}{ Plot } & \multirow[b]{2}{*}{$\begin{array}{l}\text { Factors } \\
\text { present }\end{array}$} & \multirow{2}{*}{$\begin{array}{c}\text { Primary } \\
\text { hydrology } \\
\text { indicators } \\
\text { present? }\end{array}$} & \multirow{2}{*}{$\begin{array}{c}\geq 3 \\
\text { alpha,alpha- } \\
\text { dipyridyl } \\
\text { papers } \\
\text { reacted? }\end{array}$} & \multirow[b]{2}{*}{$\begin{array}{c}\text { Hydric } \\
\text { soils } \\
\text { present? }\end{array}$} & \multicolumn{3}{|c|}{$\begin{array}{c}\text { FACU dominants removed } \\
\text { Hydrophytic vegetation present? }\end{array}$} & \multirow[b]{2}{*}{$\begin{array}{l}\geq 3 \text { IRIS } \\
\text { tubes } \\
\text { reduced }\end{array}$} \\
\hline & & & & & $\mathrm{PI}$ & DR & $\begin{array}{c}\text { Percent } \\
\text { hydrophytic } \\
\text { vegetation }\end{array}$ & \\
\hline \multicolumn{9}{|c|}{ Three-factor wetland plots } \\
\hline BJ8 & $\mathrm{V}, \mathrm{S}, \mathrm{H}$ & & & & & & & \\
\hline BJ11 & V, H, S & & & & & & & \\
\hline SB5 & $\mathrm{V}, \mathrm{H}, \mathrm{S}$ & & & & & & & \\
\hline \multicolumn{9}{|c|}{ Upland plots } \\
\hline BJ2 & $\mathrm{V}, \mathrm{H}$ & yes & no & & & & & \\
\hline BJ3 & $\mathrm{V}, \mathrm{H}$ & yes & no & & & & & \\
\hline BJ12 & none & no & no & & & & & \\
\hline BJ14 & $\mathrm{s}$ & no & no & & & & & \\
\hline SB1 & $\mathrm{V}$ & no & no & & & & & \\
\hline SB2 & $\mathrm{H}$ & yes & no & & & & & \\
\hline SB3 & $\mathrm{H}$ & yes & no & & & & & \\
\hline \multicolumn{9}{|c|}{ FACU-dominated wetland plots } \\
\hline BJ5 & $\mathrm{S}, \mathrm{H}$ & yes & yes & yes & 2.53 & 100.00 & 94.07 & \\
\hline BJ13 & $\mathrm{S}, \mathrm{H}$ & yes & yes & yes & 2.82 & 60.00 & 58.17 & \\
\hline BJ15 & $\mathrm{S}, \mathrm{H}$ & yes & yes & yes & 2.95 & 50.00 & 54.55 & \\
\hline SB4* & $\mathrm{S}, \mathrm{H}$ & yes & yes & yes & 3.07 & 50.00 & 94.41 & yes \\
\hline BJ16* & $\mathrm{S}, \mathrm{H}$ & yes & yes & yes & 3.50 & 50.00 & 50.00 & yes \\
\hline BJ1* & $\mathrm{S}, \mathrm{H}$ & yes & yes & yes & 3.62 & 33.33 & 23.81 & yes \\
\hline \multicolumn{9}{|c|}{ FACU-dominated wetland plots with problematic soils } \\
\hline BJ6 & $\mathrm{H}$ & yes & yes & no & 2.91 & 66.67 & 81.78 & yes \\
\hline BJ7 & $\mathrm{H}$ & yes & yes & no & 2.50 & 100.00 & 100.0 & yes \\
\hline BJ10 & $\mathrm{H}$ & yes & yes & no & 2.04 & 100.00 & 97.83 & yes \\
\hline
\end{tabular}




\section{Discussion}

\subsection{Reliability of NC-NE RS indicators}

The data showed that, in these wet boulder fields, primary and secondary hydrology indicators, when used together, were neither accurate nor precise. The proportion of plots containing NC-NE RS primary and secondary hydrology indicators (0.947) was significantly larger than the proportion of plots that met the wetland hydrology criterion of water within the top 12 in. of the soil surface for 14 or more consecutive days (o.632) ( $\mathrm{p}=0.042$, Table 5). They suggested the presence of wetland hydrology in 18 of the 19 plots; only one plot, SB1, did not meet the wetland hydrology criterion according to the NC-NE RS indicators. Our results show that the secondary hydrology indicators D2 and D4 (geomorphic position and microtopographic relief, respectively) are present in 17 of the 19 plots, misidentifying the hydrology in five of the seven wells that did not meet the hydrology criterion. This is a high percentage of false positive tests in this wetland type, so we propose not using secondary hydrology indicators and using only primary indicators, including 14 or more consecutive days of water within the top 12 in. of the soil surface during the growing season, to demonstrate the presence of wetland hydrology in boulder fields. Also, we caution about the use of primary hydrology indicator B8 (a sparsely vegetated concave surface). In boulder fields with highly variable topography and vegetation rooted in the folist layer, some surfaces fit the description of D2, D4, and B8 but lack wetland hydrology (SB2 and SB3). These indicators occurred as often in upland plots as they did in wetland plots.

With the D2, D4, and B8 hydrology indicators removed, 14 of the 19 wells agreed with the well data classification. $\mathrm{BJ}_{2}$ and $\mathrm{BJ}_{3}$, both upland plots, had the primary hydrology indicator A3 (saturated soils), but this was probably attributable to heavy rainfall during the sampling period rather than saturation from groundwater inputs. However, BJ6, BJ8, and BJ10, all wells that met the wetland hydrology criterion, had only two secondary indicators.

Because of the lack of association between NC-NE RS hydrology indicators and the wetland hydrology criterion, we suggest using AAD paper strips during the wettest portion of the year to confirm the presence or absence 
of wetland hydrology in boulder fields. We found that the most accurate way to determine the presence of primary hydrology indicator $\mathrm{C}_{4}$ (the presence of reduced iron) was to use the AAD paper strips. The paper strips matched the well hydrology data in 18 of the 19 wells ( $p=1.00$, Table 5 ). The liquid $\mathrm{AAD}$ test agreed with the well data in only 15 of the 19 plots, and it agreed with the paper strips in 14 of the 19 plots. Also, because the liquid must be kept out of direct sunlight and refrigerated, the paper strips were much easier to use in the field.

The proportions of plots that contained a separated surface, NC-NE RS hydric soil indicators, and IRIS tube reduction were no different from the proportion that met the wetland hydrology criterion (Table 5). The separated surface, which was absent in all plots that failed to meet the hydrology criterion and in five plots that met the criterion, was the least accurate of the three. The NC-NE RS hydric soil indicators were observed in one of seven plots without wetland hydrology and in eight of 12 plots with wetland hydrology. The IRIS tubes showed reduction in two of the seven plots without wetland hydrology and 11 of the 12 plots with wetland hydrology. Of these three variables, the IRIS tubes produced results that were closest to the well data. In two of the plots that disagreed, BJ2 and BJ3, five out of five IRIS tubes reduced, yet these plots lacked hydric soils. Higher than average precipitation in May, August, and September is probably responsible for causing reduction. In May and August, over 7 in. of rain fell, more than twice the average amount (Table 1). The third plot, BJ8, a plot with wetland hydrology, had the hydric soil indicator F3, a depleted matrix, but did not have signs of IRIS tube reduction and failed the AAD paper strip test, possibly because of limited iron in the soil. Overall, these data suggest that, in wet boulder field delineations, the NC-NE RS hydric soil indicators and the presence of a separated surface are adequate wetland indicators. However, the AAD paper strips and the IRIS tubes are the most accurate.

As the vegetation is rooted in the folist layer rather than the mineral soil surface, the presence of hydrophytic vegetation was not associated with the wetland hydrology criterion ( $\mathrm{p} \leq 0.049)$ (Table 5). However, there was no difference in the proportion of plots that met the wetland hydrology criterion and the proportion of plots that contained FACU-dominated wetland ( $\mathrm{p}=0.515)$ (Table 4). In fact, most (75.0\%) of the wetland plots in these boulder fields were dominated by FACU vegetation (Table 6). In addition, $25 \%$ of the plots that met the wetland hydrology criterion did not display hydric soil indicators. Clearly, delineations in boulder fields are 
challenging, given that they fit the description of more than one problematic wetland type described in Chapter 5 of the NC-NE RS.

\subsection{Delineating the OHWM in wet boulder fields}

The entire boulder field cannot be regulated under other WoUS. However, there may be locations within the boulder field that exhibit an OHWM. To meet the qualifications for regulation under other WoUS, there must be clearly defined surface features indicating recent flow and connectivity to a Traditional Navigable Water (TNW). Boulder fields are characterized by pockets of water, but the connection of each of these to other pockets is typically unclear. There is not a clearly defined bed or bank at the edge of the boulder field indicating the OHWM, the uppermost limit of the active channel. Therefore, the lack of surface connectivity means that the entire boulder field does not meet criteria to be regulated under other WoUS.

However, there are a few locations throughout the Saddleback boulder field with surface flow features that show connection (Fig. 9). The Burnt Jacket boulder field did not have any defined channels, possibly because it is located on a significantly shallower slope. Figure 9 (left) shows an OHWM at one ephemeral channel where the channel drops over a boulder, creating a cascade and eroding the surface. The OHWM signature is shown by the removal of leaves in the channel, a change in vegetation, and a change in slope. Figure 9 (right) shows an OHWM with water still in the channel. There is a distinct slope break associated with a change in vegetation species at the OHWM. In these circumstances, these individual channels may be regulated under other WoUS, but this small section of a reach does not apply to the entire Saddleback boulder field. 

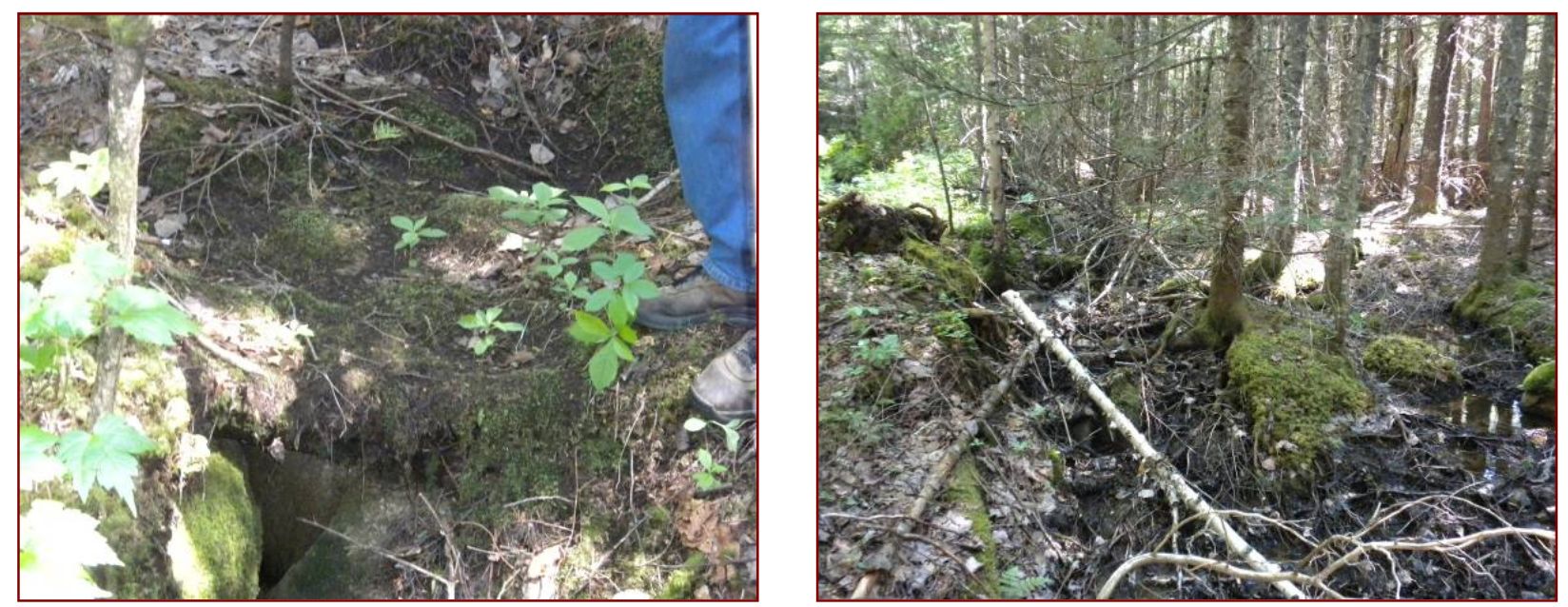

Figure 9. OHWM indicators at Saddleback in Rangeley, ME. Note the changes in slope, removal of drift such as leaves, discoloration of the frequently inundated surface, and standing water in the right center portion of the right photo.

The criteria for identifying the OHWM in boulder fields are no different than are currently followed for first-order streams in the NC-NE region. There must be a clearly defined OHWM signature that shows signs of recent flow on the surface. From our observations and our inability to demonstrate connectivity throughout the boulder fields, except at the locations with OHWM indicators, we believe that the primary flow path is shallow groundwater, which is not regulated under WoUS. As such, the next step is to determine if a boulder field meets the criteria of a wetland.

\subsection{Wetland delineation of wet boulder fields}

The boulder fields we studied in Maine were formed by glacial activity and contain water. Therefore, the delineation method we propose based on the results of this study may be used for similar glacially derived wet boulder fields, but they should not be applied to other types of boulder fields, such as those derived from talus slopes or periglacial block fields. The data suggest that wet boulder fields are an example of a problematic wetland type and consist of wetland/nonwetland mosaics. The boulder fields at the Saddleback and Burnt Jacket sites were characterized by a great deal of variation in wetland hydrology, hydric soils, vegetation, the presence or absence of a separated surface, and microtopography. Wetland hydrology, hydric soils, and a separated surface were never present on mounds or hummocks, which usually supported nonhydrophytic vegetation. Wetland hydrology, a separated surface, and hydric soils were often, but not always, present in the hollows. Vegetation was usually dominated by FACU species. Wetland and upland components were so closely associated that we 
had difficulty locating a boundary using the delineation methods described in the COE Manual (Environmental Laboratory 1987).

Instead, we recommend delineating wet boulder fields using the wetland/ nonwetland mosaic procedure described in Chapter 5 of the NC-NE RS (USACE 2009) and the flowchart (Fig. 10), which classifies all of the plots in this study correctly. We suggest initially separating the project area into three parts: continuous wetlands, continuous uplands, and heterogeneous areas with wetland and upland components. The heterogeneous areas consist of four ecological categories: uplands, three-factor wetlands, FACUdominated wetlands, and FACU-dominated wetlands with problematic soils. 


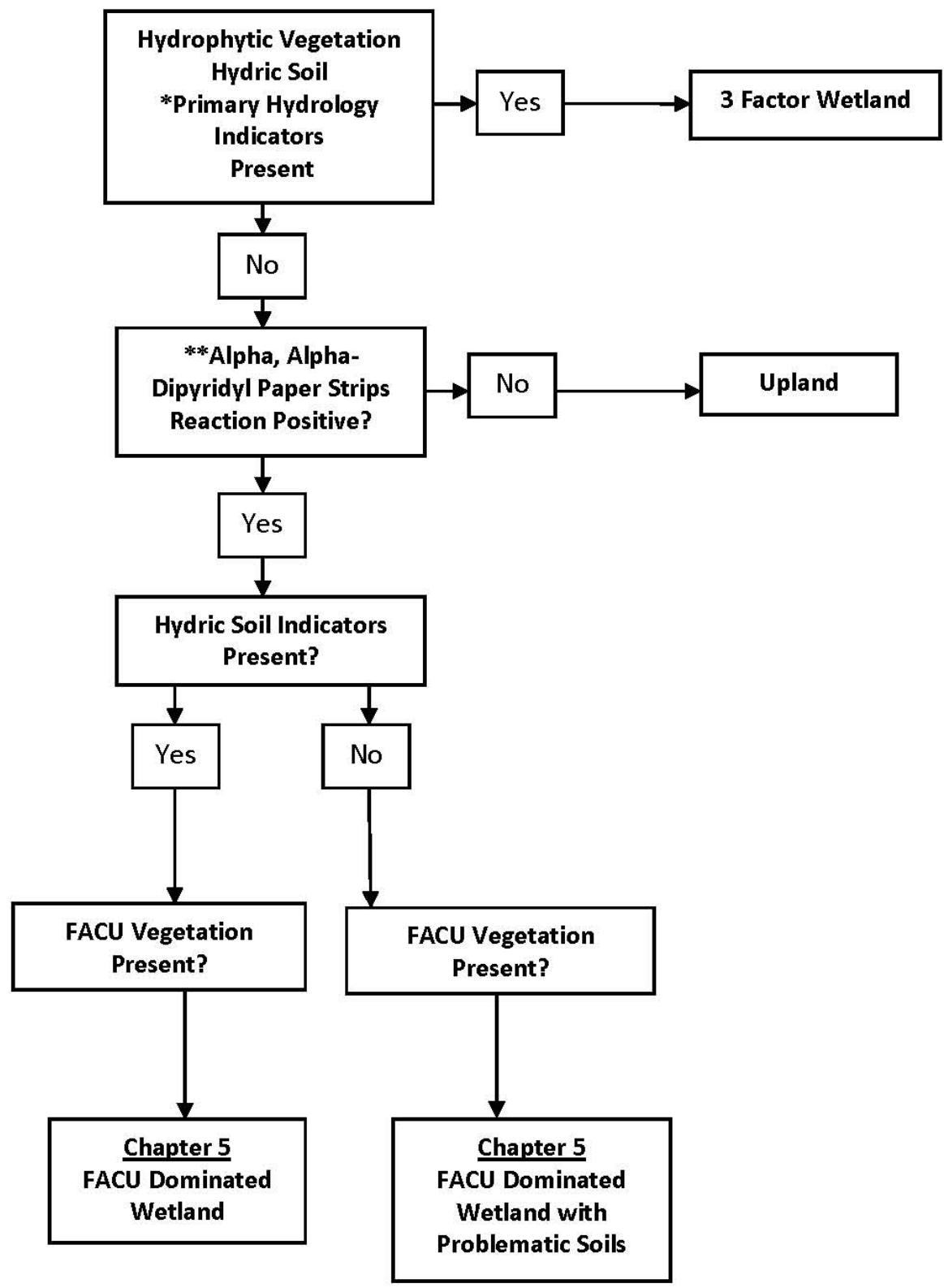

Figure 10. Methodology recommended for a boulder field delineation. *Primary hydrology indicators also include 14 consecutive days of standing water or saturated to the surface during the growing season. **Observed on several occasions over a period of 14 days.

We recommend using the following procedure. In the heterogeneous area, lay out several parallel transects, working outward towards the upland with a transect adjusted in length as required. Walk along each transect and, at every meter mark, use the flowchart (Fig. 10) to determine whether each point is upland, a three-factor wetland, a FACU-dominated wetland, or a FACU-dominated wetland with problematic soils. The flowchart is designed to categorize obvious three-factor wetland points using NC-NE RS indicators for hydrophytic vegetation, hydric soils, and primary wetland 
hydrology, including 14 or more consecutive days of water within the top $12 \mathrm{in}$. of the soil surface during the growing season. If fewer than three factors are present, $\mathrm{AAD}$ paper strips will distinguish upland points from problematic wetland points. The remaining wetland categories are considered problematic for one of two reasons: 1) the vegetation is FACU dominated, or 2) the vegetation is FACU dominated and hydric soil indicators are lacking. Points falling into these categories can be teased apart by using the instructions in Chapter 5 of the NC-NE RS (USACE 2009) or the methods section of this paper. After all transects have been sampled, use the following formula to determine the percentage of wetland in the heterogeneous area:

$$
\% \text { wetland }=\frac{\text { Number of wetland points on all transects }}{\text { Total number of points sampled on all transects }} \times 100
$$

We made wetland determinations for the 19 plots in this study using this delineation methodology and the well data. One plot was problematic. Plot BJ8 did not exhibit a strong primary hydrology indicator but had hydric soils and hydrophytic vegetation. The AAD paper strips, primary indicator $\mathrm{C} 4$, did not react, but three of five liquid drops showed the presence of reduced iron (Table 5). BJ8 had the two secondary hydrology indicators, D2 and D4, which we determined were not reliable indictors of hydrology in boulder fields because they were present in nearly all plots. The wetland hydrology data showed that this well met the hydrology criterion for 45.89 consecutive days and for $68 \%$ of the growing season (Table 3). A possible explanation for the lack of a primary hydrology indicator (other than the well data) and no change in the paper strips may be a lack of iron in the soils at this plot. 


\section{Conclusions}

Boulder fields have traditionally been viewed as either a geomorphic or geologic landscape type but not as a wetland. Because the OHWM boundary is not well defined and the connection of surface waters is often unclear, boulder fields are best regulated as wetlands. The unique features of a boulder field-from separated surfaces, to FACU-dominated vegetation, to access to soils, to hydric soil conditions, to obstacles that make it difficult to observe hydrology - combine to create a challenge for wetland delineation. In this study we evaluated the criteria for determining if a boulder field can be considered a wetland. We did this by testing the wetland indicators in boulder fields against instrumented wells for hydrology. The results of this study allowed us to develop a reliable delineation approach for boulder fields.

The hydrology monitoring wells were useful in supporting the ranking of the reliability of the indicators tested. Using these results, we developed a flow chart for delineating boulder field wetlands based on the strengths of the indicators and a similar methodology presented in the NC-NE regional supplement. We found the descending order of indicators for delineation to be: 1) water within the top 12 in. of the soil surface for 14 or more days in the growing season; 2) three out of five alpha,alpha-dipyridyl paper strips positive, observed several times over a period of 14 days; 3) three out of five IRIS tubes reduced; 4) primary hydrology indicators, hydric soil indicators, presence of a separated surface, and the use of the FACUdominated wetland approach presented in Chapter 5 of the regional supplement.

Wetland boundaries in some cases may be more obvious than in other settings. For example, at Saddleback Mountain, the boulder field has a distinct change in geomorphology from boulder field to upland where one can make a logical start to establish a wetland boundary using the presented methodology. However, areas like Burnt Jacket are large, continuous boulder fields with wetlands scattered within them. In this case, a delineator would first find plots that meet the criteria for wetlands and then, as accurately as possible, work outward to the uplands to see if a contiguous boundary can be drawn. It may require that a mosaic approach be used to delineate wetland in areas such as this. 
We recommend a few concepts for delineating wetlands be adopted based on the results of this study:

- We strongly suggest that secondary hydrology indicators and primary indicator B8, sparsely vegetated concave surface, not be used to delineate wet boulder fields.

- To determine if a plot meets the hydrology criterion, we suggest using alpha,alpha-dipyridyl paper strips. We recommend applying this test several times over a period of 14 days.

- Hydric soil indicators can be used with a reasonable level of reliability, but we suggest that alpha,alpha-dipyridyl paper strips be used to confirm a determination of nonhydric soil when a soil lacks a hydric soil indicator. IRIS tubes produce similar results, but they are not as immediate.

- It may be necessary to take several soil samples within a plot to ensure that a reasonable example was sampled. This is required, because soils are quite variable because of the frequent microtopographic changes caused by the boulders. 


\section{References}

Bailey, R. G. 1995. Description of the eco-regions of the United States. Misc. Publ. 1391. Washington, DC: U.S. Department of Agriculture Forest Service.

Berkowitz, J. F. 2009. Using IRIS tubes to monitor reduced conditions in soils-project design. ERDC TN-WRAP-09-01. Wetland Regulatory Assistance Program. Vicksburg, MS: U.S. Army Engineer Research and Development Center. http://el.erdc.usace.army.mil/elpubs/pdf/tnwrapo9-1.pdf.

Bowman, C., and H. N. Shetty. 2007. Crosstabulation (One-way, Two-way, and Multiway). In SYSTAT12: Statistics I. San Jose, CA: SYSTAT Software.

Clark, D. H., E. J. Steig, N. Potter, Jr., and A. R. Gillespie. 1998. Genetic variability of rock glaciers. Geografiska Annaler 80 A (3-4): 175-182.

Cunningham, A., and P. Wilson. 2004. Relict periglacial boulder sheets and lobes on Slieve Donard, Mountains of Mourne, Northern Ireland. Irish Geography 37(2): 187-201.

Environmental Laboratory. 1987. Corps of Engineers Wetlands Delineation Manual. Technical Report Y-87-1, U.S. Army Engineer Waterways Experiment Station, Vicksburg, MS. http://el.erdc.usace.army.mil/elpubs/pdf/wlman87.pdf (accessed 19 November 2010).

Flint, R. F. 1963. Status of the Pleistocene Wisconsin Stage in Central North America. Science 139: 402-404.

Gillrich, J. J., B. P. Allen, and R. W. Lichvar. 2011. The effect of a low-cover stratumwoody vines-on vegetation determinations made during wetland delineations. Wetlands 31: 865-873.

Gleason, H. A., and A. Cronquist. 1991. Manual of vascular plants of the Northeastern United States and adjacent Canada. New York: New York Botanical Garden.

Gretag/Macbeth. 2000. Munsell@ color. New Windsor, NY: Gretag/Macbeth.

Haeberli, W., L. King, and A. Flotron. 1979. Surface movement and lichen-cover studies at the active rock glacier near Grubengletscher, Wallis, Swiss Alps. Arctic and Alpine Research 11:421-441.

Kartesz, J. T. 2009. Floristic Synthesis of North America. Version 1.o. Chapel Hill, NC: Biota of North America Program (BONAP).

Lichvar, R. W., J. J. Gillrich, and W. R. Ochs. 2011. Discrepancies in hydrophytic determinations produced by three vegetation formulas used for wetland delineations. Wetlands 31: 603-611.

Moore, D. S., and G. P. McCabe. 2002. Inference for distributions. Introduction to the Practice of Statistics. 4th ed. New York: W.H. Freeman. 
NCDC. 2011. Weather Observation Station Record. National Climatic Data Center. http://www.ncdc.noaa.gov/oa/climate/stationlocator.html (accessed November 2011).

NRCS. 1995. WETS Table Documentation. Natural Resources Conservation Service. http://www.wcc.nrcs.usda.gov/climate/wets_doc.html (accessed November 2011).

NRCS. 2009. Web Soil Survey. United States Department of Agriculture, Natural Resources Conservation Service. http://websoilsurvey.nrcs.usda.gov/app/HomePage.htm (accessed 24 August 2010).

NRCS. 2010. Field Indicators of Hydric Soils in the United States, Version 7.o. (L.M. Vasilas, G.W. Hurt, and C.V. Noble, ed.). USDA, Natural Resources Conservation Service, in cooperation with the National Technical Committee for Hydric Soils.

NRCS. 2012. Use of alpha-alpha-Dipyridyl. Hydric Soils Technical Note 8. Natural Resources Conservation Service. http://soils.usda.gov/use/hydric/ntchs/tech_notes/note8.html.

Potter, N., Jr., and J. H. Moss. 1968. Origin of the Blue Rocks Block Field and adjacent deposits, Berks County, Pennsylvania. Geological Society of America Bulletin 79: 255-262.

Reed, P. B., Jr. 1988. National List of Plant Species that Occur in Wetlands. Biological Report 88(26.11). U.S. Department of the Interior, Fish and Wildlife Service.

Rocque, D. 2010. Personal communication, Rangeley and Greenville, Maine.

Solinst. 2010. Levelogger Series: User Guide, Software Version 3.4.0. Georgetown, Ontario, Canada: Solinst.

Sprecher, S. W. 2008. Installing Monitoring Wells in Soils, Version 1.o. Lincoln, NE: National Soil Survey Center, Natural Resources Conservation Service, USDA.

SYSTAT Software, Inc. 2007. San Jose, CA.

USACE. 2005. Technical Standard for Water-Table Monitoring of Potential Wetland Sites. U.S. Army Corps of Engineers, ERDC/TN-WRAP-05-2. Wetland Regulatory Assistance Program. Vicksburg, MS: U.S. Army Engineer Research and Development Center. http://el.erdc.usace.army.mil/wrap/pdf/tnwrapo52.pdf.

USACE. 2009. Interim Regional Supplement to the Corps of Engineers Wetland Delineation Manual: Northcentral and Northeast Region. U.S. Army Corps of Engineers, ERDC/EL 09-19. Vicksburg, MS: U.S. Army Engineer Research and Development Center. http://www.usace.army.mil/CECW/Documents/cecwo/reg/trelo9-19.pdf (accessed November 2009).

USGS. 2006. National Atlas of the United States. Generalized Geologic Map of the United States, Puerto Rico, and the U.S. Virgin Islands. U.S. Geological Survey. http://pubs.usgs.gov/atlas/geologic/ (accessed 24 August 2010). 
Wahrhaftig, C., and A. Cox. 1959. Rock glaciers in the Alaska Range. Geological Society of America Bulletin 70: 383-436.

Washburn, A. L. 1973. Periglacial Processes and Environments. New York: St. Martin's Press.

White, S. E. 1981. Alpine mass movement forms (noncatastrophic): classification, description, and significance. Arctic and Alpine Research 13(2): 127-137.

Whitty, J. E., and R. W. Arnold. 1970. Some folists on Whiteface Mountain, New York. Proceedings of the Soil Society of America 34: 653-657. 


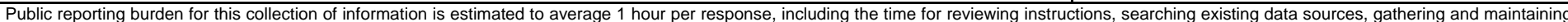

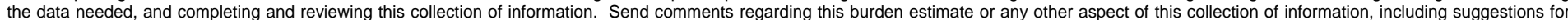

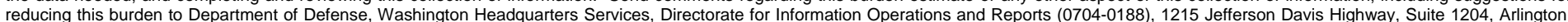

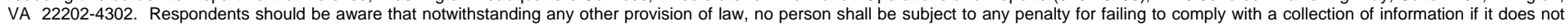
display a currently valid OMB control number. PLEASE DO NOT RETURN YOUR FORM TO THE ABOVE ADDRESS.
1. REPORT DATE (DD-MM-YYYY)
June 2012
2. REPORT TYPE
Technical Report

4. TITLE AND SUBTITLE

Testing Wetland Delineation Indicators in New England Boulder Fields

6. AUTHOR(S)

Robert W. Lichvar, Katherine E. Curtis, Jennifer J. Gillrich, and Lindsey E. Dixon

\section{PERFORMING ORGANIZATION NAME(S) AND ADDRESS(ES)}

U.S. Army Engineer Research and Development Center

Cold Regions Research and Engineering Laboratory

72 Lyme Road

Hanover, NH 03755-1290

9. SPONSORING I MONITORING AGENCY NAME(S) AND ADDRESS(ES)

10. SPONSOR/MONITOR'S ACRONYM(S)

New England District, Regulatory Division

U.S. Army Corps of Engineers

11. SPONSOR/MONITOR'S REPORT NUMBER(S)

\section{DISTRIBUTION / AVAILABILITY STATEMENT}

Approved for public release; distribution is unlimited.

Available from NTIS, Springfield, Virginia 22161.

13. SUPPLEMENTARY NOTES

\section{ABSTRACT}

We evaluated the potential for regulating wet boulder fields as wetlands or other "Waters of the US" under Section 404 of the Clean Water Act. We monitored hydrology in two boulder fields in Maine during the 2011 growing season and documented the presence/absence of hydric soil, wetland hydrology, hydrophytic vegetation, and Ordinary High Water Mark (OHWM) indicators. The wetland hydrology criterion was statistically associated with the presence of primary hydrology indicator $\mathrm{C}_{4}$, hydric soils, FACU-dominated wetland, and a separation between the folist layer and the soil surface. The occurrence of hydrophytic vegetation and the combined use of primary and secondary hydrology indicators were not associated with the wetland hydrology criterion. Wet boulder fields should be delineated as wetland/nonwetland mosaics that contain problematic wetland types. We strongly suggest discontinuing the use of secondary hydrology indicators and primary indicator B8 (sparsely vegetated concave surface) in wet boulder fields. Alpha, alpha-dipyridyl paper strips are the most accurate method for determining if a primary hydrology indicator is present. We recommend applying this test several times over fourteen days. IRIS tubes and hydric soil indicators are reliable, but we suggest that alpha,alpha-dipyridyl paper strips be used to confirm a determination of nonhydric soil when a soil lacks a hydric soil indicator.

15. SUBJECT TERMS

Boulder fields

Wetland delineation

16. SECURITY CLASSIFICATION OF:

\begin{tabular}{|c|c|c|}
\hline a. REPORT & b. ABSTRACT & c. THIS PAGE \\
$\mathrm{U}$ & $\mathrm{U}$ & $\mathrm{U}$ \\
\hline
\end{tabular}

Wetland hydrology

17. LIMITATION
OF ABSTRACT
$\mathrm{U}$

18. NUMBER
OF PAGES
48

19a. NAME OF RESPONSIBLE PERSON

19b. TELEPHONE NUMBER (include area code) 